\title{
14. DEEP SEA CARBONATE NODULES FROM THE MIDDLE AMERICA TRENCH AREA OFF MEXICO, DEEP SEA DRILLING PROJECT LEG 66 ${ }^{1}$
}

\author{
Hideki Wada, Nobuaki Niitsuma, Keinosuke Nagasawa, and Hakuyu Okada, Institute of Geosciences, \\ Faculty of Science, Shizuoka University, Shizuoka 422, Japan
}

\begin{abstract}
We collected 20 carbonate nodules from the inner trench slope deposits of the Middle America Trench area off Mexico. Carbonate nodules are found only within the methane-rich layer beneath the mixed layer of methane and hydrogen sulfide. They have been investigated by microscopic, scanning electron microscopic (SEM), X-ray diffraction, and stable isotopic analytical methods. Calcite, magnesian calcite, dolomite, and rhodochrosite were recognized as carbonate minerals. Each carbonate nodule is usually represented by single species of carbonate minerals. Carbonate nodules are subdivided into micrite nodules and recrystallized nodules according to textural features. The carbonate crystallites in each micrite nodule are equidimensional. Their sizes range from several to $30 \mu \mathrm{m}$, as revealed by SEM micrographs.

The chemical composition of calcite is changed from pure calcite to high magnesian calcite, as shown by the shift of the (104) reflection in X-ray diffraction patterns. Fe substitution for $\mathrm{Ca}$ in dolomite was also observed.

Carbon isotopic composition shows an unusually wide range-from -42.9 to $+13.5 \%_{0}-$ in PDB scale, whereas oxygen isotopic compositions of almost all the carbonate nodules are constantly enriched in ${ }^{18} \mathrm{O}$ from +3.4 to $+7.60 \%$ in PDB scale. These wide variations in carbon isotopic composition indicate several sources for the carbon in carbonate nodules. Carbon with a negative $\delta^{13} \mathrm{C}$ value was derived from biochemical oxidation of methane with a negative $\delta^{13} \mathrm{C}$ value. On the other hand, carbon with positive $\delta^{13} \mathrm{C}$ value was probably formed during methane production in an anoxic condition.
\end{abstract}

\section{INTRODUCTION}

We collected 20 carbonate nodules from cores drilled in Holes 487, 489A, 490, 491, 492, 493, and 493B, in the Middle America Trench and the adjacent shelf off Mexico (Fig. 1). Carbonate nodules occur sporadically in almost all these cores. Water depth of the holes ranges from 645 meters in Hole 493 to 4764 meters in Hole 487, which is below the carbonate compensation depth. Carbonate nodules occur in sediments from early Miocene to Quaternary age. They were first called to the attention of marine researchers in the Japan Trench Transect during Leg 56, where they occur well below the carbonate compensation depth (Okada, 1980).

Only a few isotopic studies have been made on authigenic carbonate phases in deep sea environments (Milliman et al., 1969; Anderson and Lawrence, 1976; Hein et al., 1979), except for evaporation phases in the Mediterranean Sea (Hahn-Weinheimer et al., 1978; McKenzie and Ricchiuto, 1978). Carbonate nodules in sedimentary rocks now exposed on land have been isotopically studied (Weber et al., 1964; Galimov et al., 1968; Fritz et al., 1971; Suss and Kolodny, 1972; Hirabayashi, 1977), and carbonate nodules in unconsolidated deep sea sediments have recently been reported by Hein et al. (1979). Studying the condition of formation of such carbonate nodules will clarify the origin of carbonate nodules so common in geosynclinal sedimentary se-

\footnotetext{
${ }^{1}$ Initial Reports of the Deep Sea Drilling Project, Volume 66.
}

quences (Okada, 1980). The present report gives results of carbon and oxygen isotopic, petrographic, and mineralogic investigations of the carbonate nodules and enclosing muds.

\section{SAMPLES}

All the carbonate nodules were collected from soft mud cores. Because the surrounding mud is almost unconsolidated, nodules can easily be distinguished from mud. Typical carbonate nodules are subangular to subrounded in shape, with diameters of several centimeters. Layered limestone can be recognized by such features as layered internal structures in specimens. Figure 2 shows simplified stratigraphic columns of selected Leg 66 cores and gas composition in the sediment. The geological time scale in these columns was determined from the paleomagnetic stratigraphy (Niitsuma, this volume). Sampling positions in the cores are also shown (Fig. 2).

Carbonate nodules occur below methane and hydrogen sulfide. The odor of hydrogen sulfide was discernible in a zone a few tens of meters sub-bottom. Below this zone, gas expansion voids are produced by separation and expansion of dissolved methane and carbon dioxide due to abrupt release of pressure. Methane is the dominant phase, and small amounts of $\mathrm{CO}_{2}$ and traces of ethane and propane have been measured in the gas (Didyk and Beghtel, this volume). These columnar zonations of gas production are common in anaerobic sediments and have been explained by the fact that methane production is initiated after the reduction of $\mathrm{SO}_{4}{ }^{2-}$ is completed (Nissenbaum et al., 1972; Irwin et al., 1977). 


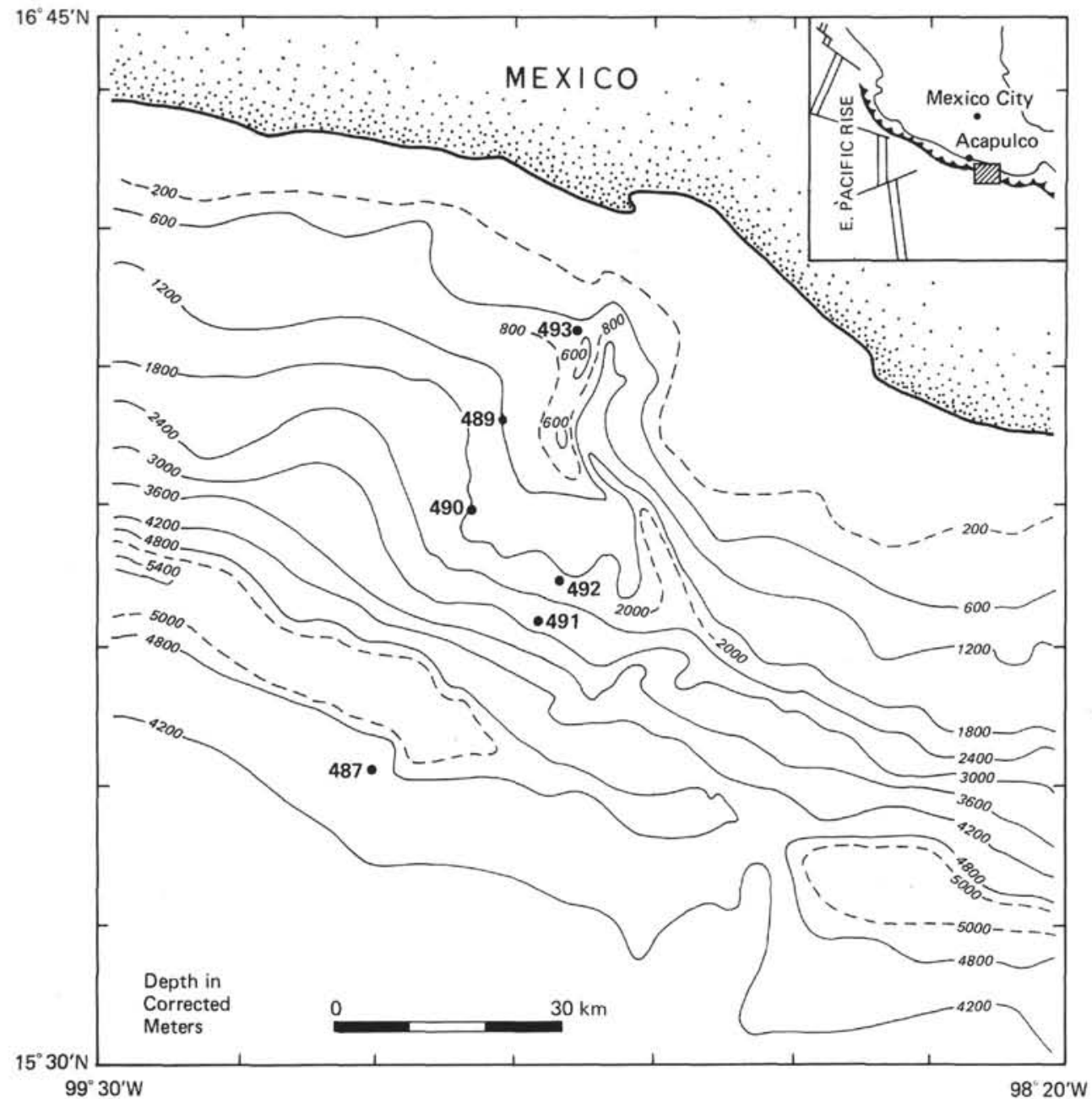

Figure 1. Location of Leg 66 sites in this study.

\section{METHODS}

Carbonate nodules were examined by means of microscopic and SEM observation, X-ray diffraction analysis, and carbon and oxygen isotopic analysis. In addition, X-ray diffraction and carbon and oxygen isotopic analysis were carried out on the enclosing soft muds in which carbonate nodules were found.

Carbonate nodules were cut into thin slices and rinsed with distilled water to remove $\mathrm{NaCl}$. Then they were either made into thin sections for microscopic observations or dried and ground to fine powder for X-ray analysis and carbon and oxygen isotopic analysis. Photomicroscopic investigations on the thin sections were carried out with the Zeiss Photomicroscope III at Shizuoka University.

In order to investigate the degree of recrystallization, we observed the texture and crystal morphology on fracture surfaces of selected carbonate nodules by SEM. Samples used for the SEM photography are chips a few millimeters across, with fresh fracture surfaces. The SEM was a JEOL JSM-35 installed at Shizuoka University.

$\mathrm{X}$-ray diffraction analysis was carried out in order to determine mineral composition of carbonate nodules. The X-ray diffractometer was a Toshiba ADG-102 at Shizuoka University.

For isotopic analysis, the carbonates were decomposed with concentrated phosphoric acid according to the standard method of McCrea (1950). Carbon dioxide gas was collected by decomposing the calcite with acid for 1 hour, and the dolomite and rhodochrosite for 4 to 72 hours, in vacuo and at a temperature of $25^{\circ} \mathrm{C}$. Carbon dioxide was examined by mass-spectrometric analysis. The mass spectrometer was a Nier-McKinney-type instrument, Varian Mat $\mathrm{CH}-7$, in the Department of Earth Sciences at Nagoya University.
Carbon and oxygen isotopic compositions are described in the usual $\delta$-notation relative to the PDB standard (Craig, 1957), as follows:

$$
\delta(\%)=\left\{\left(R_{\text {sample }} / R_{\mathrm{PDB}}\right)-1\right\} \times 1000,
$$

where $R$ is ${ }^{13} \mathrm{C} /{ }^{12} \mathrm{C}$ or ${ }^{18} \mathrm{O} /{ }^{16} \mathrm{O}$ in sample and standard. We used a working standard NU-1 $\mathrm{CO}_{2}$ gas evolved from the reaction of reagent marble and phosphoric acid which was frequently calibrated with respect to the NBS-20 standard. Analytical errors in the carbon and oxygen isotopic measurements are less than \pm 0.2 per mill.

The constituent minerals of air-dried muds were identified with an X-ray diffractometer. Furthermore, a differential thermal analysis (DTA) and an infrared absorption analysis were made in order to confirm the identification of carbonate minerals in muds. Clay minerals were identified using oriented aggregates on glass slides, which were prepared from the air-dried samples. These samples were dispersed in water and their finer-grained portions collected by decantation and dried on glass slides. The oriented aggregates were examined with an $\mathrm{X}$-ray diffractometer in an air-dried state as well as after ethylene glycol solvation.

To obtain the oxygen and carbon isotopes of calcite in mud, the mud, rinsed with distilled water, was heated in air at $300^{\circ} \mathrm{C}$ for 1 hour in order to remove the water absorbed by the clay minerals. The method for the decomposition of calcite in mud was similar to the one used for carbonates in nodules.

To determine the isotopic composition of organic carbon, the soft mud was first treated with $1 \mathrm{~N}-\mathrm{HCl}$ to remove carbonate carbon. The residues were then carefully rinsed with distilled water through a glass 

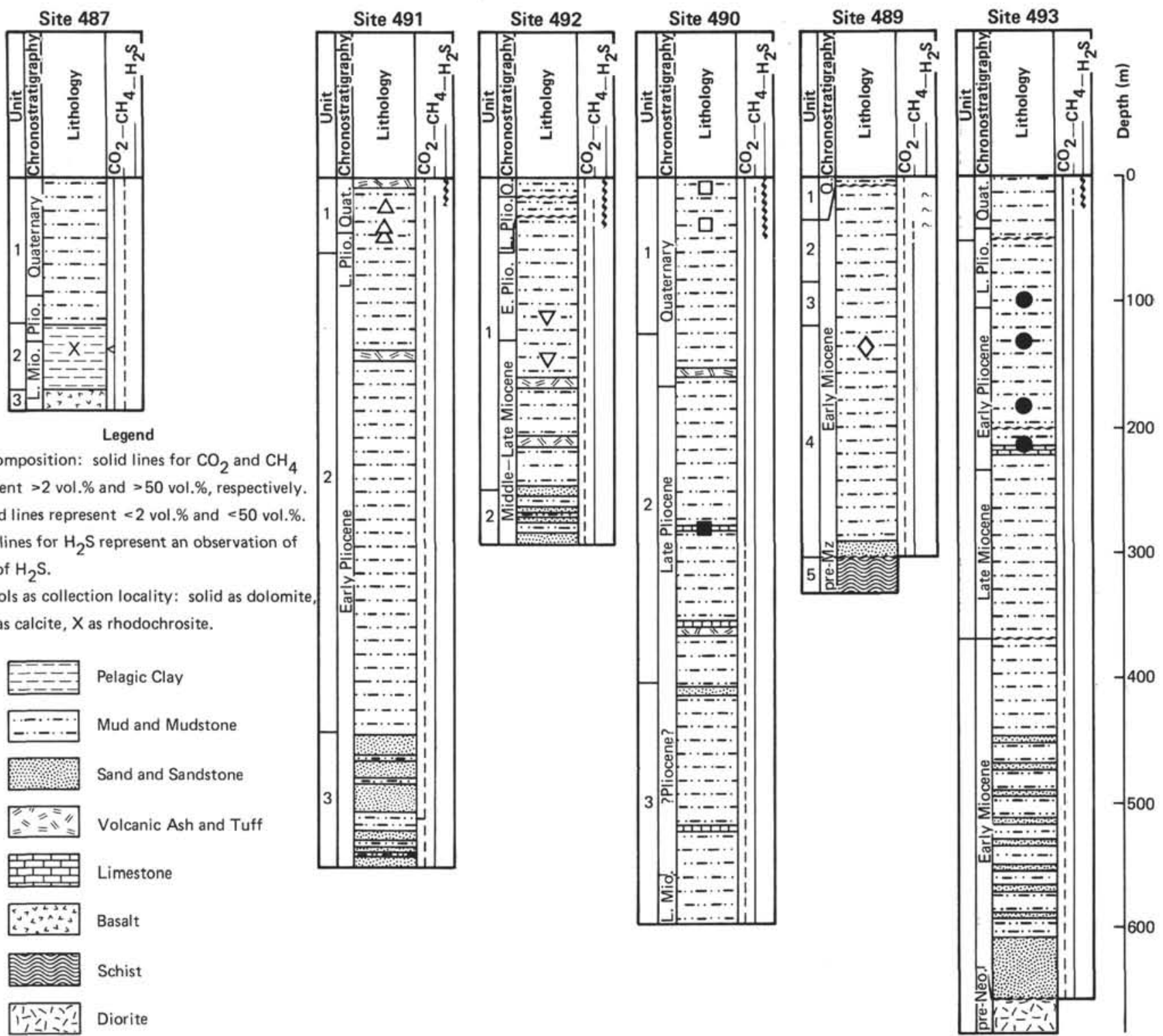

Figure 2. Simplified stratigraphic columns for Leg 66 sites in this study.

filter previously heated to $450^{\circ} \mathrm{C}$ to remove any organic substances. The carbonate-free samples were dried at $110^{\circ} \mathrm{C}$ and a several-milligram aliquot of carbon put into a vessel and combusted to $\mathrm{CO}_{2}$ in a pure oxygen atmosphere of about $400 \mathrm{~mm} \mathrm{Hg}$. The combustion was forcibly completed by circulating oxygen with a glass fan and by passing the evolved gas through a column filled with copper oxide at $750^{\circ} \mathrm{C}$. The $\mathrm{CO}_{2}$ was finally trapped with liquid nitrogen and further purified against $\mathrm{SO}_{2}$ by an $n$-pentane frozen technique developed by Mizutani and Oana (1973). Carbon dioxide thus purified was subjected to mass-spectrometric analysis.

\section{RESULTS}

\section{Textural and Mineralogical Features}

Carbonate nodules were examined microscopically and scanning electron microscopically as well as by $\mathrm{X}$-ray diffraction analysis.

\section{Microscopic Observations}

Petrographic features and mineral constituents of selected carbonate nodules are listed in Table 1, and photographs of selected thin sections are shown in Plates 1,2 , and 3 . The carbonate nodules are mostly yellowish brown (10YR 5/4). They can be subdivided into three mineralogical types, calcite, dolomite, and rhodochrosite, discussed in detail later. The texture is either micritic or recrystallized, regardless of mineralogy.

Micritic nodules are characterized by an oval pellet structure (Plate 1) and range from 1 to $2 \mathrm{~mm}$ in long diameter. They sometimes contain silt-sized quartz and feldspar grains, and the matrix between pellets is filled with slightly coarser grains (Plate 1, Figs. 1 and 2). According to Folk's (1962) terminology, micrites with pellets are classified as pelmicrite.

Calcite nodules in Holes 489A, 490, 491, and 492 are cryptocrystalline in texture and therefore calcite micrite, except for one sample (490-2-1; Plate 3, Fig. 4), which is somewhat coarsely recrystallized and is composed of blade-shaped calcite crystals about $40 \mu \mathrm{m}$ in length. All these nodules contain terrigenous grains and foraminif- 
Table 1. Petrographic features of carbonate nodules collected from Leg 66 cores.

\begin{tabular}{|c|c|c|}
\hline $\begin{array}{c}\text { Sample } \\
\text { (interval in } \mathrm{cm} \text { ) }\end{array}$ & & Description \\
\hline $487-16-1,13-16$ & $\mathrm{rR}$ & $\begin{array}{l}\text { Recrystallized limestone with rare } \\
\text { quartz, composed as a whole of } \\
\text { coarsely crystallized rhodochrosite. }\end{array}$ \\
\hline $489 A-12-2,146-148$ & $\mathrm{cMf}$ & $\begin{array}{l}\text { Biotite-feldspar-quartz-foraminifer- } \\
\text { bearing micrite. Chambers of most } \\
\text { foraminifers are filled with pyrite. }\end{array}$ \\
\hline $490-1-4,82-84$ & $\mathrm{cMf}$ & $\begin{array}{l}\text { Chlorite-biotite-bearing pelmicrite } \\
\text { with rare diatoms and foraminifers } \\
\text { and common plagioclase and } \\
\text { quartz. }\end{array}$ \\
\hline $490-2-1,10-12$ & $\mathrm{cMp}$ & $\begin{array}{l}\text { Chlorite-biotite-palagonite-bearing } \\
\text { pelmicrite with rare diatoms and } \\
\text { common feldspar and quartz. } \\
\text { Micrite is composed wholly of } \\
\text { blade-shaped calcite crystals (5-10 } \\
\mu \text { m long). }\end{array}$ \\
\hline $490-29-4,128-132$ & $\mathrm{dMpf}$ & $\begin{array}{l}\text { Pelmicrite with dolomite layers, } \\
\text { containing rare chlorite, diatoms, } \\
\text { and foraminifers and common } \\
\text { biotite, feldspar, and quartz. Pellets } \\
\text { range in size from } 1.2 \text { to } 2.4 \mathrm{~mm} \text {. }\end{array}$ \\
\hline $490-37-3,0-5$ & $\mathrm{cMp}$ & $\begin{array}{l}\text { Chlorite-biotite-bearing, } \\
\text { feldspar-quartz-rich silty pelmicrite. }\end{array}$ \\
\hline $491-4-1,16-18$ & cMf & $\begin{array}{l}\text { Foraminifer-chlorite-biotite- } \\
\text { bearing, feldspar-quartz-rich micrite } \\
\text { with rare zircon and common pyrite } \\
\text { microlite, containing silty clasts. }\end{array}$ \\
\hline $491-4-2,31-34$ & $\mathrm{cMp}$ & $\begin{array}{l}\text { Biotite-muscovite-bearing, } \\
\text { feldspar-quartz-rich, micrite with } \\
\text { common pyrite microlite. }\end{array}$ \\
\hline $491-4-3,98-100$ & $\mathrm{cMpf}$ & $\begin{array}{l}\text { Foraminifer-biotite-muscovite- } \\
\text { bearing, feldspar-quartz-rich } \\
\text { pelmicrite with rare pyroxene. }\end{array}$ \\
\hline $491-6-1,4-6$ & $\mathrm{cMpf}$ & $\begin{array}{l}\text { Foraminifer-bearing pelmicrite with } \\
\text { rare biotite and muscovite and com- } \\
\text { mon pyrite, feldspar, and quartz. } \\
\text { An open cavity ( } 2.2 \times 0.20 \mathrm{~mm}) \\
\text { between pellets is preserved, though } \\
\text { calcite microspars grow to some ex- } \\
\text { tent along the cavity wall. }\end{array}$ \\
\hline $491-5-4,65-67$ & $\mathrm{cMpf}$ & $\begin{array}{l}\text { Foraminifer-biotite-bearing pelmi- } \\
\text { crite with common feldspar and } \\
\text { quartz. }\end{array}$ \\
\hline $491-6-1,20-22$ & $\mathrm{cMpf}$ & $\begin{array}{l}\text { Biotite-muscovite-bearing pelmicrite } \\
\text { with rare diatoms and foraminifers } \\
\text { and common feldspar and quartz; } \\
\text { calcite veinlets. }\end{array}$ \\
\hline $492-13-1,81-83$ & $\mathrm{cMf}$ & $\begin{array}{l}\text { Biotite-bearing micrite with rare zir- } \\
\text { con and foraminifers and common } \\
\text { diatoms, quartz, and feldspar. }\end{array}$ \\
\hline $492-16-4,135-137$ & $\mathrm{cMpf}$ & $\begin{array}{l}\text { Pelmicrite with rare foraminifers } \\
\text { and common feldspar, quartz, and } \\
\text { diatoms. Diatoms are mostly replac- } \\
\text { ed with pyrite. Pellets are } 1-3 \mathrm{~mm} \\
\text { in size. }\end{array}$ \\
\hline $493-3-2,10-15$ & $\mathrm{dR}$ & $\begin{array}{l}\text { Feldspar-quartz-bearing dolomite } \\
\text { with rare biotite. }\end{array}$ \\
\hline $493-8-2,49-51$ & $\mathrm{dMf}$ & $\begin{array}{l}\text { Diatom-feldspar-quartz-bearing } \\
\text { micrite with common foraminifers. }\end{array}$ \\
\hline $493-11-3,54-56$ & $\mathrm{dR}$ & $\begin{array}{l}\text { Feldspar-quartz-bearing dolomite } \\
\text { with common diatoms. }\end{array}$ \\
\hline 493B-10-1, 20-22 & $\mathrm{dR}$ & $\begin{array}{l}\text { Feldspar-quartz-bearing dolomite } \\
\text { with rare biotite. }\end{array}$ \\
\hline 493B-10-1, 51-55 & $\mathrm{dRp}$ & $\begin{array}{l}\text { Feldspar-quartz-bearing dolomite } \\
\text { with rare biotite, showing weak } \\
\text { pellet structure. }\end{array}$ \\
\hline 493B-10-1, 51-53 & $\mathrm{dRp}$ & $\begin{array}{l}\text { Feldspar-quartz-biotite-bearing } \\
\text { dolomite with weak pelletal struc- } \\
\text { ture. }\end{array}$ \\
\hline
\end{tabular}

Note: $\mathrm{c}=$ calcite, $\mathrm{d}=$ dolomite, $\mathrm{r}=$ rhodochrosite, $\mathrm{R}=$ recrystallized, $\mathrm{M}=$ micrite, $\mathrm{p}=$ pelletal structure, $\mathrm{f}=$ foraminifers. rare = $<$ or $\leq 1 \%$, bearing $=1-5 \%$, common $=5-15 \%$, rich $=15-25 \%$. eral fossils. Terrigenous grains include silt-sized quartz, feldspar, and biotite. Some fractures are completely filled with secondary calcite microspars (Plate 2, Fig. 3), whereas original cavities between pellets are sometimes empty (Plate 1, Fig. 4). In Sample 491-6-1, 20-22 cm, a burrow filled with lime mud and secondary calcite spars contains pellets (Plate 2, Fig. 2). In Sample 490-37-3, an organic burrow is also filled with small pellets (Plate 2, Fig. 1).

Dolomite nodules occur in Holes 490, 493, and 493B. They are subdivided into micritic dolomite (Plate 2, Fig. 4, and Plate 3, Fig. 1) and coarsely recrystallized dolomite (Plate 3, Fig. 2). The former is very similar in texture to the cryptocrystalline calcite nodules described in the foregoing. Foraminiferal fossils are well preserved in micritic dolomite (Plate 2, Fig. 4), whereas they are indiscernible in recrystallized dolomite. The latter is characterized by rhombic crystals of almost equal size-about $30 \mu \mathrm{m}$ (Plate 3 , Fig 2 ). In this recrystallized dolomite, original textures are almost lost, and the terrigenous components quartz, feldspar, and biotite are rarely found.

Only a single rhodochrosite nodule was recovered (Sample 487-16-1). It has a uniform, coarsely crystallized mosaic texture (Plate 3, Fig. 3). Detrital quartz grains are rarely found.

\section{SEM Observation}

In order to clarify further the microscopic features, carbonate nodules were examined with a scanning electron microscope. The SEM micrographs of fracture surfaces of selected calcite and dolomite specimens are shown in Plates 4 to 10 .

Calcite nodules are micritic and recrystallized in texture, as previously described. Plate 4, Figures 1 and 2, shows the blade-shaped calcite crystals in Sample 490$2-1$. Figure 1 shows calcite crystals in penetration twins. This unique feature is different from all other calcites in this report. Detrital mica occurs rarely in recrystallized calcite. SEM micrographs show fracture surfaces on calcite micrites with some distinctly describable features. Plate 5, Figures 1 and 2, shows fracture surfaces in Samples 490-1-4 and 491-6-1, 20-22 cm, respectively. Both are classified as calcite micrite. The SEM micrographs show quartz, feldspar, and mica with flat surfaces to be common. Diatom fragments also occur (Plate 5, Fig. 1, bottom half). The matrix of these fracture surfaces is composed of calcite aggregates. Calcite aggregates shown in Plate 5, Figure 1, are less than 10 $\mu \mathrm{m}$ and sometimes rounded (Plate 5, Fig. 1, upper left corner). Plate 5 , Figure 2 , shows calcite aggregates as noticeably larger grains $(10-30 \mu \mathrm{m})$ that form a subangular lamellae. Thus we can recognize two types of the calcite micrite.

Fracture surfaces of recrystallized dolomites are shown in Plates 6 and 7. Terrigenous components such as quartz, feldspar, and mica together with fragments of foraminifers are rarely found in these dolomites. Plates 6 and 7 show the outstanding crystallographic features of two types of dolomites. Plate 6, Figure 1 (bottom half) shows some cubic crystals, though the surface of the cubes is not clear and the edges are rounded; other 
fracture surfaces consist of anhedral dolomite. In a close-up photo (Plate 7, Fig. 1), recrystallized dolomites seem to form angular lamellae of uniform size (20-30 $\mu \mathrm{m})$. The surfaces of these lamella structures may correspond to the cleavage of dolomite crystal. Dolomite crystals in Sample 493B-10-1, 51-53 cm show perfectly a euhedral rhombohedron. The grain-size of the drusy dolomite ranges from several to $40 \mu \mathrm{m}$, whereas the host nodule has an equidimensional texture with grains from 10 to $20 \mu \mathrm{m}$.

Plates 8 and 9 show different fracture surfaces of dolomite micrites. Terrigenous particles are common, but the frequency of occurrence is lower than that of calcite micrite (Plate 5, Figs. 1,2). Surface features of these dolomite micrites are characterized by platy dolomite lamellae. The dolomite plates in Sample 493-8-2 are almost identical in size-about $10 \mu \mathrm{m}$, which is markedly larger than the dolomite plates in Sample 490$29-4$, which are less than a few microns. The lamella structure is considered to be similar to the surface structure of Sample 493-11-3, which we classified as recrystallized dolomite (Plate 6, Fig 1, and Plate 7, Fig. 1).

Plate 10 shows the fracture surface of rhodochrosite with cleavage. This surface feature represents the perfect recrystallization of rhodochrosite.

\section{X-Ray Diffraction Analysis}

The interplanar spacing of the (104) plane of carbonates is listed in Table 2, and the typical diffraction diagrams are given in Figure 3. Because carbonate nodules, except for rhodochrosite (Sample 487-16-1), contain minor amounts of quartz, the (101) reflection of quartz was used as an internal standard for correction of the $d(104)$ value of carbonates.

Table 2. Carbonate minerals in nodules and muds.

\begin{tabular}{|c|c|c|c|c|}
\hline Hole & Core/Section & $\begin{array}{l}\text { Interval } \\
\text { (cm) }\end{array}$ & Mineral & $\begin{array}{c}d(104) \\
(\AA)\end{array}$ \\
\hline \multicolumn{5}{|c|}{ Nodule } \\
\hline 487 & $16-1$ & $13-16$ & rhodochrosite & 2.848 \\
\hline 489A & $12-2$ & $146-148$ & calcite & $3.016^{\mathrm{b}}$ \\
\hline 490 & $1-4$ & $82-84$ & calcite & 3.010 \\
\hline 490 & $2-1$ & $10-12$ & calcite & 3.010 \\
\hline 490 & $29-4$ & $128-132$ & dolomite & $2.891^{\mathrm{b}}$ \\
\hline 491 & $4-1$ & $16-18$ & calcite & $2.999^{\mathrm{b}}$ \\
\hline 491 & $5-4$ & $65-67$ & calcite & $3.004^{\mathrm{b}}$ \\
\hline 491 & $6-1$ & $4-6$ & calcite & $3.000^{\mathrm{b}}$ \\
\hline 491 & $6-1$ & $20-22$ & calcite & $2.991^{b}$ \\
\hline 492 & $13-1$ & $81-83$ & calcite & 3.020 \\
\hline 492 & $16-4$ & $135-137$ & calcite & 3.019 \\
\hline 493 & $3-2$ & $10-15$ & dolomite & 2.894 \\
\hline 493 & $8-2$ & $49-51$ & dolomite & 2.894 \\
\hline 493 & $11-3$ & $54-56$ & dolomite & 2.893 \\
\hline 493B & $10-1$ & $20-22$ & dolomite & 2.903 \\
\hline 493B & $10-1$ & $51-53$ & dolomite & 2.901 \\
\hline \multicolumn{5}{|l|}{ Mud } \\
\hline 493 & $11-3$ & $50-52$ & calcite & 3.036 \\
\hline 493 & $27-5$ & $2-4$ & dolomite & 2.909 \\
\hline 493B & $10-1$ & $51-53$ & dolomite & 2.903 \\
\hline
\end{tabular}

Note: $\mathrm{b}=$ broad reflection.
The $d(104)$ value in calcite nodules ranges from 3.036 to $2.991 \AA$. Calcite in mud (Sample 493-11-3) has a $d(104)$ value of $3.036 \AA$, which is typical for pure calcite (Goldsmith et al., 1961). Calcites in Samples 489A-12-2, 490-1-4, 490-2-1, 492-13-1, and 492-16-4 have smaller $d(104)$ values $(3.010-3.020 \AA)$ than the typical pure calcite. Calcite in Sample 491-6-1, 20-22 cm shows the smallest $d(104)$ value: $2.991 \AA$. It seems that the distribution of $d(104)$ values changes predictably between the pure calcite (in mud, Sample 493-11-3), and the calcite of the smallest value, represented by Sample 491-6-1, $20-22 \mathrm{~cm}$. The small $d(104)$ value may be due to the substitution of $\mathrm{Mg}$ for $\mathrm{Ca}$ in calcite. The magnesite components in calcites calculated by X-ray (104) reflections are listed in Table 4 . The relationship between lattice constants and $\mathrm{MgCO}_{3}$ content in magnesian calcite was studied by Goldsmith et al. (1961). As shown in Table 2, the (104) reflection of these calcites is broader than that of typical pure calcite-for example, the ratio of height to width of the (104) peaks of calcites represented by small $d(104)$ values $(2.991,2.999,3.000,3.004 \AA)$ averages 46 , and the ratio of intermediate $d(104)$ values of calcites averages 72 .

The $d(104)$ value of dolomite is from 2.891 to 2.909 $\AA$, which is slightly higher than that of typical dolomite $(2.886 \AA)$. Dolomite nodules at Site 493 give a slightly smaller $d$ (104) value -2.893 to $2.894 \AA$-relative to that of the 493B-10-1 samples-2.901 to $2.903 \AA$. Although the dolomite in Sample 490-29-4 has the smallest $d(104)$ value $-2.891 \AA$-the reflection peak is broad with a shoulder on the small-angle side, as shown in Figure 3. On the other hand, except for Sample 490-29-4, dolomites show sharp (104) reflections. For example, the height/width parameter of the (104) peak in Sample 49029-4 is 46 , whereas those of other dolomites are from 81 to 125 and average 97 . This suggests that the dolomite in Sample 490-29-4 is heterogeneous and that much of it may represent a phase with larger $d(104)$ values. Hence as regards the $d(104)$ value, the dolomite in Sample $490-29-4$ is similar to the large $d(104)$ dolomite in the 493B-10-1 series samples. As shown in Figure 2, all dolomites examined show distinct superstructure reflections, (101), (105), etc. (Lippmann, 1973), on X-ray diagrams. This indicates a regular alternation of $\mathrm{Ca}$ and $\mathrm{Mg}$ layers. The large $d(104)$ value may be due to the substitution of $\mathrm{Fe}$ for $\mathrm{Mg}$, which was confirmed by the coloring of a fired sample after differential thermal analysis (DTA). The common substitution of $\mathrm{Fe}$ in marine authigenic carbonates was suggested by Hein et al. (1979).

The mineralogical composition of selected muds was examined by X-ray diffraction analysis (Table 3 ). The terrigenous components quartz, feldspar, mica, kaolinite, and smectite are ubiquitous. Samples 493-27-5 and 493-10-1 are mostly dolomite. The weight percent of dolomite in mud is estimated at $43 \%$ by thermogravimetry. In Sample 493-11-3, calcite occurs in mud, whereas the carbonate nodule in mud is composed only of dolomite. 


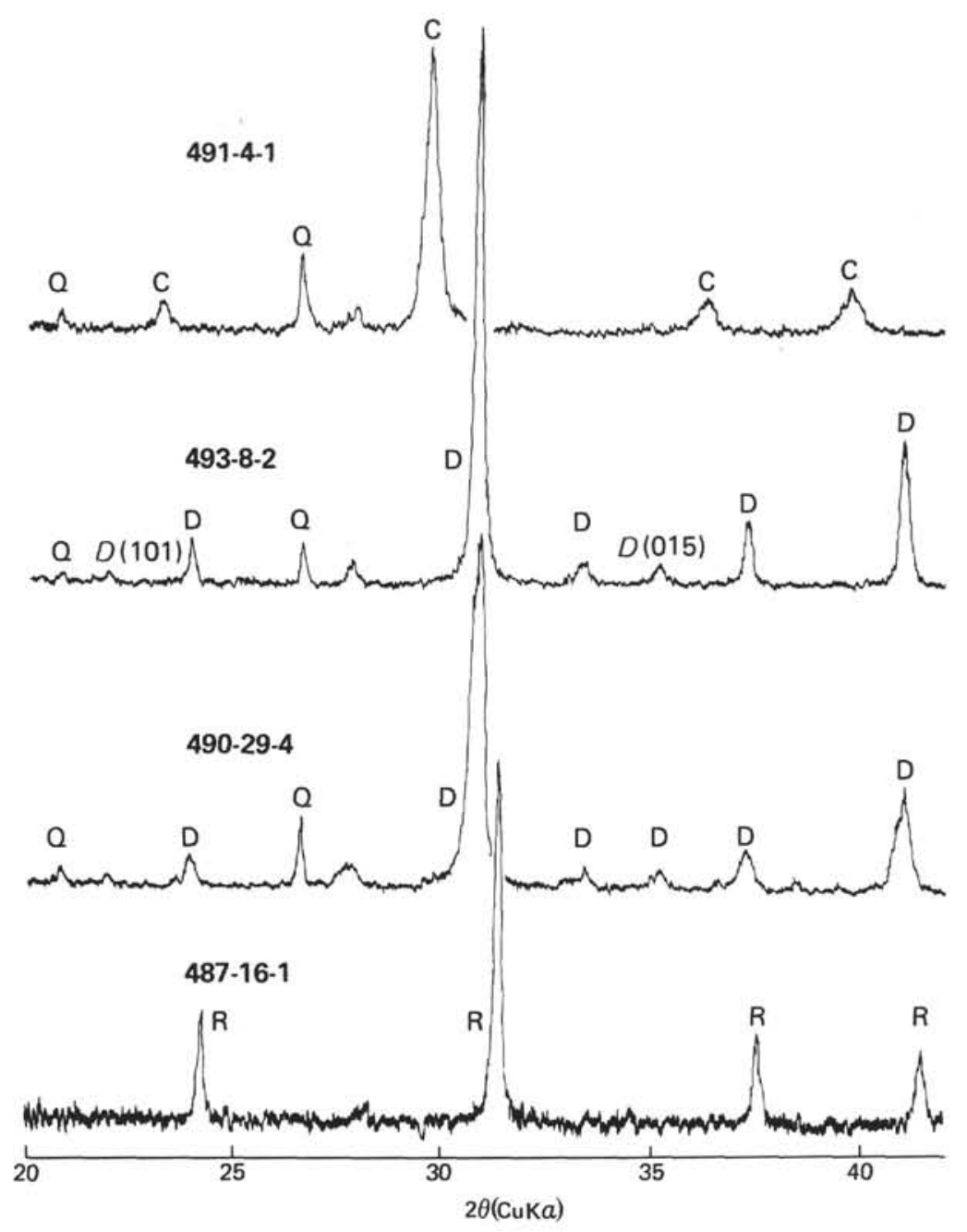

Figure 3. Examples of X-ray reflection diagrams of carbonate nodules from Leg 66.

( $\mathrm{C}=$ calcite, $\mathrm{D}=$ dolomite, $\mathrm{Q}=$ quartz, $\mathrm{R}=$ rhodochrosite. $)$

Table 3. Mineral composition of muds.

\begin{tabular}{lccccccccc}
\hline & \multicolumn{7}{c}{$\begin{array}{c}\text { Mica } \\
\text { (incl. }\end{array}$} \\
Hole & Core/Section & $\begin{array}{c}\text { Interval } \\
\text { (cm) }\end{array}$ & Quartz & Feldspar & illite) & Kaolinite & Smectite & Calcite & Dolomite \\
\hline 491 & $5-4$ & $65-67$ & + & + & ++ & ++ & ++ & & \\
491 & $6-1$ & $4-6$ & ++ & + & ++ & ++ & ++ & & \\
491 & $6-1$ & $20-22$ & + & + & ++ & ++ & ++ & & \\
492 & $13-1$ & $87-89$ & + & + & ++ & ++ & ++ & + & + \\
493 & $11-3$ & $50-52$ & + & + & ++ & ++ & + & + & ++ \\
493 & $27-5$ & $2-4$ & + & + & + & + & + & + & ++ \\
$493 B$ & $10-1$ & $51-53$ & + & + & + & + & & + & + \\
\hline
\end{tabular}

Note: $++=$ abundant, $+=$ present.

\section{Carbon and Oxygen Isotopic Compositions}

For the oxygen isotopic composition, we used the fractionation factor between $\mathrm{CO}_{2}$ evolved by acid treatment and carbonate determined by Sharma and Clayton (1965). Their values are as follows:

$$
\begin{aligned}
\alpha_{\mathrm{CO}_{2} \text {-calcite }} & =1.01025, \\
\alpha_{\mathrm{CO}_{2} \text {-dolomite }} & =1.01109,
\end{aligned}
$$

and

$$
\alpha_{\mathrm{CO}_{2} \text {-rhodochrosite }}=1.01012 \text {, }
$$

where $\alpha$ is defined as $\alpha=\left({ }^{18} \mathrm{O} /{ }^{16} \mathrm{O}\right)_{\mathrm{CO}_{2}} /\left({ }^{18} \mathrm{O} /{ }^{16} \mathrm{O}\right)$ carbonate. Oxygen isotopic compositions of magnesian calcites were further subtracted $0.06 \%$ times the mole $\%$ of $\mathrm{MgCO}_{3}$ in calcite from the measured $\delta^{18} \mathrm{O}$ value (Tarutani et al., 1969). 
Carbon and oxygen isotopic compositions of carbonates in nodules and mud are listed in Table 4 and shown in Figure 4. $\delta^{13} \mathrm{C}$ values of calcite in nodules fall in a wide range $(-0.2$ to $-42.9 \%)$, but $\delta^{18} \mathrm{O}$ values show a relatively small variation $(+1.6$ to $6.2 \%)$. The range of $\delta^{18} \mathrm{O}$ values within any individual core is especially small (within $1 \%$, Fig. 4). The highly negative $\delta^{13} \mathrm{C}$ values in calcite are unusual in comparison with the $\delta^{13} \mathrm{C}$ value of deep sea carbonates reported by Hein et al. (1979).

$\delta^{13} \mathrm{C}$ values of dolomite in nodules also fall in a wide range ( -14.3 to $+13.5 \%$ ). The highly positive values of dolomite are also unusual. $\delta^{18} \mathrm{O}$ values of dolomite show a small range and positive values $(+4.3$ to $+5.9 \%$ ). These positive $\delta^{18} \mathrm{O}$ values of calcite and dolomite are fairly enriched in ${ }^{18} \mathrm{O}$ in comparison with $\delta^{18} \mathrm{O}$ values for benthic foraminifers $(<+3 \%)$ (Boersma and Shackleton, 1977).

The $\delta^{18} \mathrm{O}$ value of rhodochrosite shows the highest positive value $(+7.6 \%$, Table 4$)$.

Table 4 lists carbon isotopic compositions and concentrations of total organic carbon in selected mud samples. $\delta^{13} \mathrm{C}$ value of organic carbon in mud enclosing the carbonate nodules shows a small range $(-20.8$ to $-22.0 \%$ ). These values correspond to the range of $\delta^{13} \mathrm{C}$ values of living marine plankton or organic matter from pelagic sediments at low and middle latitudes (Sackett and Thompson, 1963; Degens et al., 1968; Aizenshtat et al., 1973).

\section{DISCUSSION}

Several remarkable mineralogical and textural features of carbonate nodules from deep sea sediments have been revealed by photomicroscopic, SEM micrographic, and X-ray diffraction analyses. Isotopic results seem to be closely related with these features, because the isotopic compositions of carbonate nodules may depend on such parameters as temperature, $p \mathrm{H}$, constituent mineral species of carbonate, source of carbon and oxygen and so forth. Therefore we will discuss the origins of carbon and oxygen in carbonate as well as the relationship between petrographic and mineralogical features and isotopic results.

\section{Calcite}

We can recognize two terminal carbon isotopic compositions and an intermediate composition: (1) $\delta^{13} \mathrm{C}$ and $\delta^{18} \mathrm{O}$ values are nearly zero per mil; (2) extremely negative value of $\delta^{13} \mathrm{C}$ and constant positive value of $\delta^{18} \mathrm{O}$; and (3) intermediate values of $\delta^{13} \mathrm{C}$ between (1) and (2).

Group (1) consists of Samples 489A-12-2 (nodule) and 493-11-3 (calcite in mud). Sample 489A-12-2 is micrite with foraminifers. $\delta^{13} \mathrm{C}$ and $\delta^{18} \mathrm{O}$ values of Sample 489A- $12-2$ are -0.2 and $+1.6 \%$, respectively. These values are identical to those of benthic foraminifers (e.g. Boersma and Shackleton, 1977). This sample was collected beneath the unconformity between Quaternary and upper Miocene deposits and occurs as layers. Many foraminiferal remains are still preserved. The $\delta^{18} \mathrm{O}$ value of calcite in mud from Sample 493-11-3 $(-3.4 \%)$ is slightly more negative than for the foraminifers $(+3--2 \%)$. Calcite in this group is considered to be normal marine carbonate derived from biogenic carbonate.

Group (2) consists of the calcite nodules in Samples 491-6-1, 20-22 cm and 491-4-1, 16-18 cm, which are pelmicrite and micrite, respectively. A carbonate nodule in Sample 491-6-1, 20-22 cm has a burrowing structure of dark gray pelmicrite several millimeters across, which contains a small pellet. The isotopic distribution on the pellet in this structure is shown in Figure 5 and indicates that the pellet is especially depleted in ${ }^{13} \mathrm{C}\left(\delta^{13} \mathrm{C}\right.$ values of -42.9 and $-41.0 \%$ ) and that the matrix has a $\delta^{13} \mathrm{C}$ value of $-31.0 \%$. Pelmicrite clasts formed prior to the matrix; subsequently the carbon source must have been enriched in ${ }^{13} \mathrm{C}$ before the matrix was precipitated. In spite of this enrichment of ${ }^{13} \mathrm{C}$, carbon isotopic composition of this nodule is still extraordinarily depleted in ${ }^{13} \mathrm{C}$ in comparison with ordinary marine calcite.

Table 4. Sample descriptions and isotopic compositions of carbonate nodules collected from deep sea cores in IPOD/DSDP Leg 66, Middle America Trench area off Mexico.

\begin{tabular}{|c|c|c|c|c|c|c|c|c|c|c|c|}
\hline \multirow[b]{2}{*}{ Hole } & \multirow[b]{2}{*}{ Core/Section } & \multirow[b]{2}{*}{$\begin{array}{l}\text { Interval } \\
(\mathrm{cm})\end{array}$} & \multirow[b]{2}{*}{$\begin{array}{l}\text { Water } \\
\text { Depth } \\
\text { (m) }\end{array}$} & \multirow[b]{2}{*}{$\begin{array}{l}\text { Sub-bottom } \\
\text { Depth } \\
\text { (m) }\end{array}$} & \multirow[b]{2}{*}{$\begin{array}{l}\text { Carbonate } \\
\text { Mineralogy }\end{array}$} & \multirow[b]{2}{*}{$\begin{array}{c}\mathrm{MgCO}_{3} \text { in } \\
\text { Calcite } \\
(\mathrm{mol} \mathrm{\%})\end{array}$} & \multirow[b]{2}{*}{ Occurrence } & \multicolumn{2}{|c|}{ Carbonate } & \multicolumn{2}{|c|}{ Organic Carbon } \\
\hline & & & & & & & & $\begin{array}{l}\delta^{18 \mathrm{O}} \\
(\% \circ) \\
(\mathrm{PDB})\end{array}$ & $\begin{array}{l}{ }_{\delta^{13} \mathrm{C}} \\
(\%) \\
(\mathrm{PDB})\end{array}$ & $\begin{array}{l}\delta^{13} \mathrm{C} \\
(\% \circ) \\
(\mathrm{PDB})\end{array}$ & (wt. \%) \\
\hline 487 & $16-1$ & $13-16$ & 4764 & 134 & rhodochrosite & & & +7.6 & -2.9 & & \\
\hline 489A & $12-2$ & $146-148$ & 1240 & 134 & calcite & 6.4 & layered limestone & +1.6 & -0.2 & & \\
\hline 490 & $1-4$ & $82-84$ & 1761 & 6 & calcite & 8.5 & $8 \times 2 \mathrm{~cm}$ nodule, same color as mud & +5.3 & -10.1 & & \\
\hline 490 & $2-1$ & $10-12$ & 1761 & 10 & calcite & 8.5 & $8 \times 2 \mathrm{~cm}$ nodule, same color as mud & +6.2 & -6.2 & & \\
\hline 490 & $29-4$ & $128-132$ & 1761 & 273 & dolomite & & layered dolomite & +5.9 & -14.0 & & \\
\hline 491 & $4-1$ & $16-18$ & 2883 & 29 & calcite & 12.6 & nodule & +5.0 & -34.3 & & \\
\hline 491 & $5-4$ & $65-67$ & 2883 & 43 & calcite & 10.8 & nodule & +3.9 & -12.8 & -20.8 & 1.5 \\
\hline 491 & $6-1$ & $4-6$ & 2883 & 48 & calcite & 12.2 & nodule & +4.5 & -17.5 & -21.4 & 1.9 \\
\hline 491 & $6-1$ & $20-22$ & 2883 & 48 & calcite & 15.8 & nodule & +4.0 & -37.5 & -21.5 & 1.7 \\
\hline 492 & $13-1$ & $81-83$ & 1935 & 112 & calcite & 5.0 & layered limestone & +3.1 & -18.1 & -21.9 & 1.4 \\
\hline 492 & $16-4$ & $135-137$ & 1935 & 143 & calcite & 5.4 & limestone block & +3.2 & -13.5 & & \\
\hline 493 & $3-2$ & $10-15$ & 645 & 131 & dolomite & & calcareous mud clast with opal vein & +4.7 & +11.9 & & \\
\hline 493 & $8-2$ & $49-51$ & 645 & 180 & dolomite & & & +4.3 & +5.4 & & \\
\hline 493 & $11-3$ & $54-56$ & 645 & 210 & dolomite & & 3-cm angular nodule & +4.3 & +13.5 & -22.0 & 3.2 \\
\hline 493 & $11-3$ & $50-52$ & 645 & 210 & calcite & 0.0 & calcite in mud & -3.4 & -0.3 & & \\
\hline 493B & $10-1$ & $20-22$ & 645 & 98 & dolomite & & layered dolomite & +5.7 & -13.4 & & \\
\hline 493B & $10-1$ & $51-53$ & 645 & 99 & dolomite & & layered dolomite & +5.5 & -14.3 & & \\
\hline
\end{tabular}




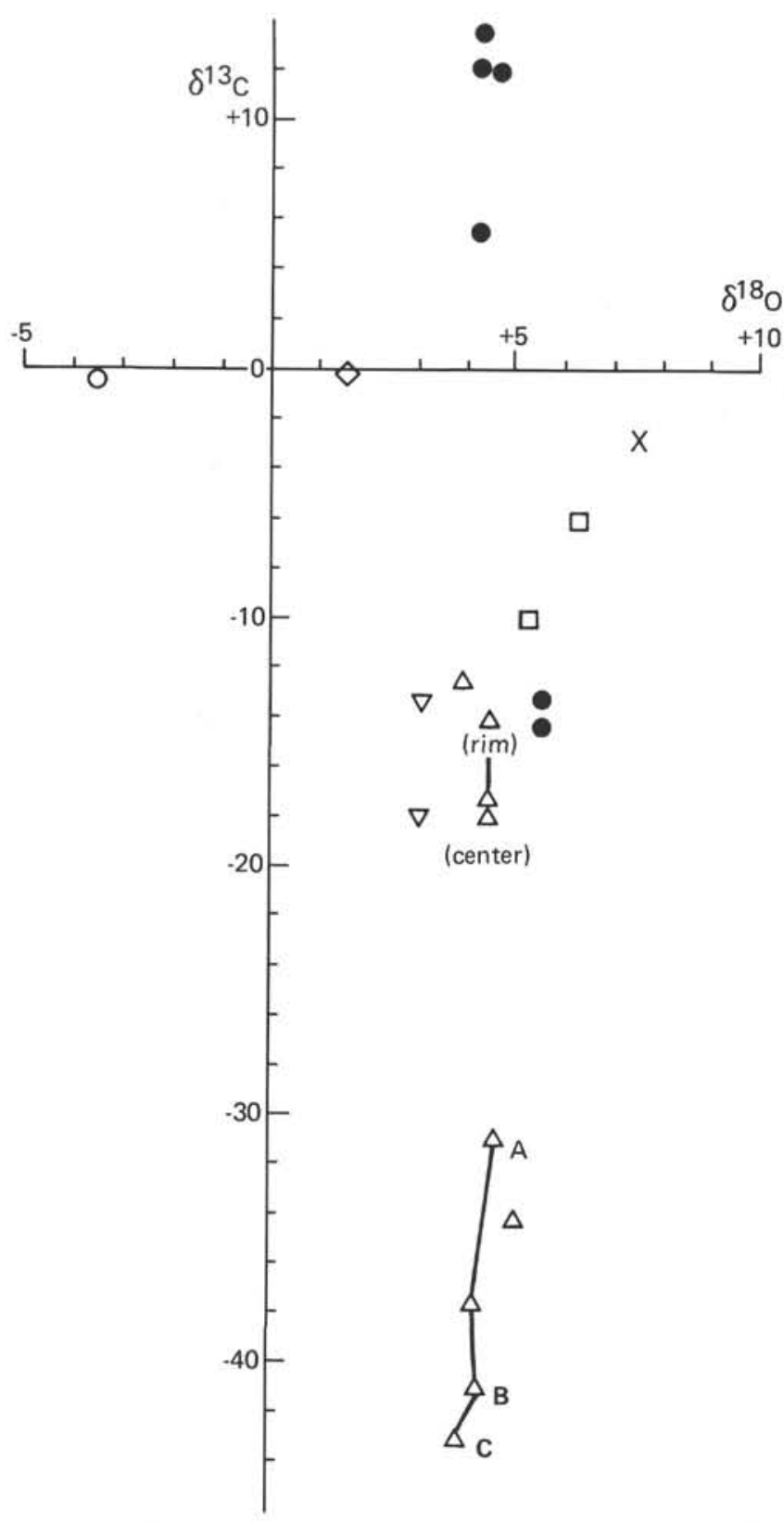

Figure 4. Carbon and oxygen isotopic compositions of carbonate nodules collected from Leg 66 cores, Middle America Trench area off Mexico. (Symbols are same as in Fig. 2; solid symbols indicate the dolomite nodules. See Fig. 5 for subsample locations A, B, and C.)

In spite of the large difference of carbon isotopic composition (about $10 \%$ ) between a pellet in a burrow and the matrix, oxygen isotopic compositions of both of them show a relatively constant value $(4.7$ to $5.3 \%)$.

Sample 491-6-1, 20-22 cm corresponds to the micrite with large grains of calcite aggregates described in the preceding SEM observation. Furthermore, the $d(104)$ value of calcite in these micrites (Samples 491-6-1, 20-22 $\mathrm{cm}$ and 491-4-1) gives the smallest values (2.991 and $2.999 \AA$, respectively), and their (104) reflections are broad in shape. These mineralogical features may be related to the extraordinarily light carbon isotopic compositions of this group.

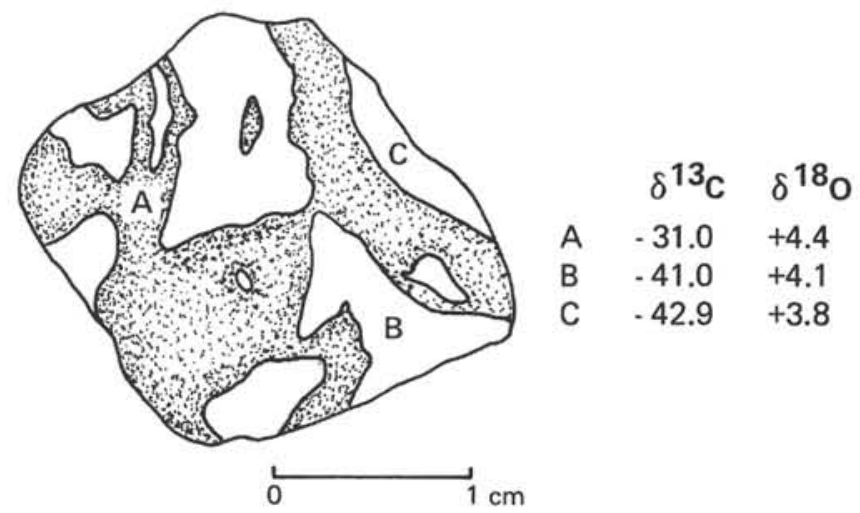

Figure 5. Distribution of carbon and oxygen isotopic compositions in Sample 491-6-1, 20-22 cm.

This unusually light carbon content in carbonates cannot be explained by routine chemical oxidation produced by marine organisms or by bacterial reduction of sulfate, because the carbon isotopic composition of carbon dioxide evolved could be identical with that produced by marine organic matter ( -21 to $-22 \%$, Cheney and Jensen, 1965; Sackett and Thompson, 1963). Such light carbon isotopic compositions may result from the formation of carbon dioxide from methane by chemical or microbiological oxidation (Rosenfeld and Silverman, 1959; Hodgeson, 1966; Hathaway and Degens, 1969; Claypool et al., 1973; Roberts and Whelan, 1975). Because occurrence of calcite nodules is restricted to core layers containing methane, it is plausible that the carbon was derived from the oxidation of methane.

In group (3) $\delta^{13} \mathrm{C}$ values vary widely $(-6.2$ to $-18.5 \%$ ), and $\delta^{18} \mathrm{O}$ values range from +3.1 to $+6.2 \%$. Calcite nodules in this group are classified either as micrite or as pelmicrite in texture, except for Sample 490-2-1, which is composed of blade-shaped recrystallized calcite. The recrystallized calcite of Sample 490-2-1 occurs exclusively in calcite nodules. $\delta^{13} \mathrm{C}$ and $\delta^{18} \mathrm{O}$ values of this recrystallized calcite are -6.2 and $+6.2 \%$, respectively. As shown in Figure 3, isotopic compositions of this blade-shaped calcite are somewhat atypical. Sample 491-6-1, 4-6 cm is a typical rounded carbonate nodule 2 to $3 \mathrm{~cm}$ across. In order to determine the isotopic distribution in such a nodule, isotopic analysis was made on both the inner and outer parts. The central part is more depleted in ${ }^{13} \mathrm{C}\left(\delta^{13} \mathrm{C}=-18.5 \%\right.$ ) than the outer part $\left(\delta^{13} \mathrm{C}=-14.1 \%\right)$. The average $\delta^{13} \mathrm{C}$ value of the whole nodule is $-17.5 \%$. This tendency in carbon isotopic zoning was also reported by Galimov et al. (1968) and Hirabayashi (1977). Carbon isotopic variation in a zoned structure, however, is within the range of variation of calcites in this group.

Carbon in calcites of this group has a $\delta^{13} \mathrm{C}$ value between that of marine organic carbon in this area $(-21$ to $-22 \%_{0}$ ) and that of marine carbonate (near $0 \%$ ).

Figure 6 shows, further, that except for two Site 492 samples, carbon isotopic composition of calcite decreases with increasing $\mathrm{MgCO}_{3}$ content in calcite. SEM micrographs reveal that calcite with extremely light carbon is characterized by relatively large lamellae on the 


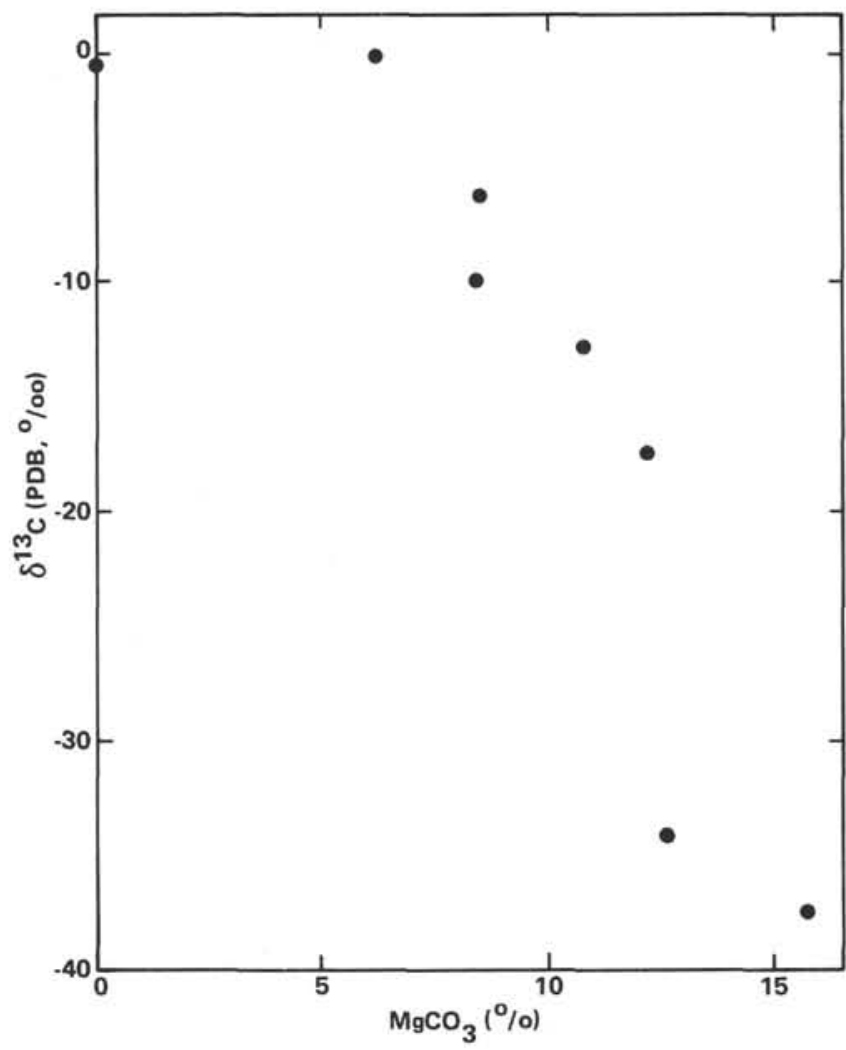

Figure 6. Relationship between carbon isotopic composition of calcites and $\mathrm{MgCO}_{3}$ content.

fracture surface. Thus calcite with the lightest carbon can be considered as an end member component in isotopic, mineralogical, and textural features. Carbon in those calcites with intermediate $\delta^{13} \mathrm{C}$ values may be a mixture of $\mathrm{CO}_{2}$ dissolved in seawater and $\mathrm{CO}_{2}$ derived from methane oxidation process. One cannot, however, eliminate the possible role of $\mathrm{CO}_{2}$ derived from chemical and bacterial degradation of organic matter during sulfate-reduction processes.

${ }^{13} \mathrm{C}$-depleted calcite nodules are found at relatively shallow depth and are enriched in magnesium. High magnesian calcite is formed by a rapid increase of $p \mathrm{H}$ value probably due to microbiological reduction processes (Milliman et al., 1969). This agrees with the observation that carbonate nodules occur only beneath the hydrogen sulfide layer. Although it cannot be concluded without knowing the chemical composition of pore water in cores, carbonate nodules may be precipitated at relatively shallow subdepth in association with the microbiological production of methane.

\section{Dolomite}

Dolomite occurs only in Holes 490, 493, and 493B. It has two types of texture: micritic and recrystallized. Recrystallized dolomite nodules are composed of rhombic crystals of uniform size and seem to be homogeneous in texture. A micritic dolomite in Sample 493-8-2 is also homogeneous in texture, though some fragments of microfossil and terrigenous components are randomly scattered. Because only one sample-490-29-4-of micritic dolomite, with some dolomite veinlets, occurs, its chemical composition is slightly dispersed. In order to investigate the distribution of isotopic compositions in a nodule, analyses were made for several parts of the recrystallized dolomite nodule in Sample 493B-10-1, 51$53 \mathrm{~cm}$. As shown in Figure 7, carbon isotopic composition of this nodule is -14.6 to $-16.8 \%$, but there is no pattern of the distribution of $\delta^{13} \mathrm{C}$ values such as we observed in calcite. $\delta^{18} \mathrm{O}$ values of some parts of the nodule are surprisingly constant $-+5.6 \pm 0.2 \%$.

Dolomite nodules are divided into two groups according to carbon isotopic compositions: (1) unusually positive $\delta^{13} \mathrm{C}$ values $(+5.4$ to $+13.5 \%$ ) and (2) significantly negative values $(-13.5$ to $-14.3 \%$ ).

The first group of dolomites, with heavy carbon, includes Samples 493-3-2, 493-8-2, and 493-11-3. Sample 493-8-2 is characterized by pelmicritic dolomite, and the other two are recrystallized. The second group of dolomites, with light carbon, includes Samples 490-29-4 and 493B-10-1. Sample 490-29-4 is also characterized by micritic dolomite. Sample 493B-10-1 comprises recrystallized dolomite with euhedral rhombohedra. According to SEM micrographs of these dolomite nodules, it is evident that Sample 490-29-4 is somewhat atypical in that the morphology of the dolomite crystals shows successive enlargement. Furthermore, X-ray diffraction analysis shows that the $d(104)$ values of Sample 493B-10-1 are much larger (2.901 and $2.903 \AA$ ) than in Hole 493 samples (2.893-2.894 $\AA$ ). Thus the dolomite with extremely heavy carbon shows crystallographic and mineralogical end member features. Sample 490-29-4 shows another example of such extreme end member features in carbon isotopic compositions. In the following, we consider the origin of carbons with different isotopic compositions.

\section{Heavy Carbon Dolomite}

The unusually heavy carbon isotopic composition of dolomite cannot be explained by precipitation from normal marine water, as can the calcite with unusually light carbon discussed in the preceding section. Carbon in marine sediments is mainly bicarbonate in seawater and the organic material of marine and terrestrial organisms. When carbon dioxide is derived from these car-

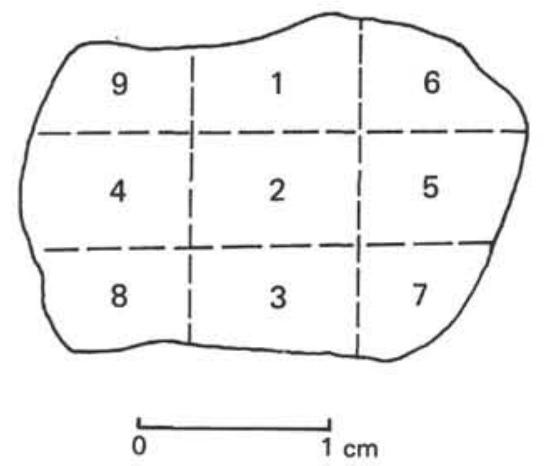

$\begin{array}{ll}\delta^{13} \mathrm{C} & \delta^{18} \mathrm{O} \\ -14.6 & +5.6 \\ -15.4 & +5.7 \\ -15.1 & +5.6 \\ -16.3 & +5.5 \\ -14.9 & +5.7 \\ -14.3 & +5.2 \\ -16.8 & +5.6\end{array}$

Figure 7. Distribution of carbon and oxygen isotopic composition in Sample 493B-10-1, 51-53 cm. 
bons by chemical or bacterial oxidation, $\delta^{13} \mathrm{C}$ values of precipitated carbonate does not deviate much more widely than from +3 to $-25 \%$. The unusually heavy carbon isotopic compositions found in the present study - as high as $+13.5 \%$ - has also been reported for carbonate minerals by Murata et al. (1969), Deuser (1970), Curtis et al. (1972), De Giovani et al. (1974), and Shidlowski et al. (1976) and can be explained only by considering the budget of carbon species in a closed system under anaerobic conditions. Nissenbaum et al. (1972) reported heavy carbon isotopic composition $\left(\delta^{13} \mathrm{C}\right.$ value $+17.3 \%$ ) for dissolved $\mathrm{CO}_{2}$ in interstitial water of sediments in a fjord in British Columbia. They concluded that the enrichment of ${ }^{13} \mathrm{C}$ in dissolved $\mathrm{CO}_{2}$ is caused by the reduction of carbon dioxide, in which process light carbon is preferentially removed by methane-forming bacteria using molecular or organically available hydrogen. In other studies, it is shown that heavy carbon may have resulted from equilibration between carbon dioxide and ${ }^{13} \mathrm{C}$-depleted methane $(\mathrm{Mu}-$ rata et al., 1969; De Giovani et al., 1974). In the special cases of Precambrian dolomite and Antarctic carbonates, enrichment of ${ }^{13} \mathrm{C}$ was brought about in a closed basin by preferential removal of the light carbon (Shidlowski et al., 1976) and by continuous evaporation and dissolution of carbonate in an Antarctic environment (Nakai et al., 1975), respectively. Deuser (1970) also reported extremely heavy dolomites $\left(\delta^{13} \mathrm{C}+14.1\right.$ to $+20.9 \%$ ) of Quaternary age dredged from submarine canyons within the continental shelf of the northeastern United States. He concluded that this heavy carbon value was produced by an isotopic fractionation between methane and residual carbon during degradation of a limited amount of organic carbon with incorporation of biogenic carbon.

As noted earlier, carbonate nodules occur in methanebearing sediments beneath hydrogen-sulfide-bearing sediments. The production of hydrogen sulfide and methane is considered to be caused by bacterial activity in an anaerobic environment. The fact that carbonate nodules form only under special conditions may be related to biogenic processes. Dolomite with heavy carbon may have formed authigenically using heavy $\mathrm{CO}_{2}$ from one of the three sources: (1) $\mathrm{CO}_{2}$ equilibrated with methane caused by large fractionation between them; (2) $\mathrm{CO}_{2}$ formed by fermentation of organic matter by which methane with light carbon was also formed (see Irwin et al., 1977); or (3) $\mathrm{CO}_{2}$ formed by isotopic fractionation during degradation of organic carbon with incorporation of biogenic carbon (see Deuser, 1970). We consider the second or third process the most likely. There is no evidence that $\mathrm{CO}_{2}$ and $\mathrm{CH}_{4}$ could effectively be equilibrated at low temperatures, as Nissenbaum et al. (1972) also pointed out. In fact, although micritic calcite (Sample 491-6-1, 20-22 cm) occurs in sediments containing methane, its average ${ }^{13} \mathrm{C}$ value $(-37.5 \%$ ) is far lower than what we expect from equilibrium between $\mathrm{CO}_{2}$ and $\mathrm{CH}_{4}$.

\section{Light Carbon Dolomite}

In contrast, dolomite nodules with light carbon $(-13$ to $-14 \%$ ) have a different carbon origin from heavy carbon nodules. As Cheney and Jensen (1965) report, $\mathrm{CO}_{2}$ derived from oxidation of organic carbon could make the carbon deficient in ${ }^{13} \mathrm{C}$. The light carbon of the nodules in question may also have derived from organic carbon through chemical or biological oxidation.

\section{Rhodochrosite}

One sample collected at Site 487 is recrystallized rhodochrosite. The site is located on the ocean floor beyond the Middle America Trench. $\delta^{13} \mathrm{C}$ and $\delta^{18} \mathrm{O}$ values of the rhodochrosite are -2.9 and $+7.6 \%$, respectively. Although carbon in rhodochrosite is considered to be derived from normal dissolved $\mathrm{CO}_{2}$ in an open marine environment, $\delta^{18} \mathrm{O}$ is highly enriched in all the samples.

Oxygen isotopic compositions of carbonate nodules, except for calcites of the first group of calcite nodule, show greater ${ }^{18} \mathrm{O}$-enrichment than normal marine carbonates. This enrichment can be ascribed to the evaporation of water in a closed basin or lagoon environment. Deuser (1970) showed that the formation and high $\delta^{18} \mathrm{O}$ values of dolomites dredged from submarine canyons off northeastern United States may be due to evaporation near the edge of the continental shelf during the period of lowered sea level. Regarding Leg 66 samples, the soft sediments on the continental crust in which dolomite nodules are found were successively deposited during the late Miocene and Quaternary. Therefore these nodules cannot have formed in such shallow marine environments as lagoons.

When calcite is precipitated in equilibrium with seawater at $0^{\circ} \mathrm{C}$, it has a $\delta^{18} \mathrm{O}$ value of $4.8 \%$ (Epstein and Lowenstam, 1953). $\delta^{18} \mathrm{O}$ values of some calcites and dolomites show that these carbonates are precipitated from water further enriched in ${ }^{18} \mathrm{O}$ about $1 \%$, even if the calcites are precipitated at $0^{\circ} \mathrm{C}$. It is conceivable that ${ }^{18} \mathrm{O}$ enrichment is produced by squeezing water depleted in ${ }^{18} \mathrm{O}$ through clay layers (Kharaka and Berry, 1973). The oxygen isotopic composition of interstitial water in deep sea sediments, however, generally decreases in ${ }^{18} \mathrm{O}$ with sub-bottom depth (Lawrence, 1973, 1974; Perry et al., 1976).

\section{Organic Carbon}

Land-derived plant material in the middle latitudes may be distinguished from marine organic matter by its carbon isotopic composition (Sackett, 1964; Smith and Epstein, 1971; Hedges and Parker, 1976). Therefore organic carbons in these sediments are mainly derived from marine organisms. Sample 493-11-3, which has the lightest organic carbon $\left(\delta^{13} \mathrm{C}=-22.0 \%\right)$, is situated only about $20 \mathrm{~km}$ offshore. Sample 491-5-4, which has the heaviest carbon $\left(\delta^{13} \mathrm{C}=-20.8 \%{ }_{0}\right)$, is collected from 
the apron of the continental slope about $60 \mathrm{~km}$ offshore. In this context, we do not consider the lightest carbon $(-22.0 \%)$ to derive from typical marine organisms in the area at the time of sedimentation but to be contaminated by terrestrial material $\left(\delta^{13} \mathrm{C}\right.$ value approx. $-25 \%$ ). Furthermore, these $\delta^{13} \mathrm{C}$ values show no isotopic exchange of organic carbon through the production of methane, which is ubiquitous in the cores.

\section{SUMMARY}

Carbonate nodules collected from Leg 66 cores were mainly magnesian calcite, dolomite, and rhodochrosite in mineral composition. Carbonate nodules may have been authigenically formed under anaerobic conditions. Carbonate nodules are texturally grouped into two types: micritic and recrystallized. Carbon isotopic composition of calcite has an unusually negative range of values- $-42.9 \%$ to $-0.2 \%$. Calcite nodules have two sources of carbon: normal marine carbonate with a $\delta^{13} \mathrm{C}$ value of about $0 \%$, and biochemical oxidation of methane, with an unusually negative $\delta^{13} \mathrm{C}$ value. $\mathrm{MgCO}_{3}$ contents in calcite nodules increase with decreasing $\delta^{13} \mathrm{C}$ values of calcites. Calcite with the lightest carbon is characterized by relatively large lamellae and can be considered an end member component in isotopic, mineralogical, and textural features. For dolomite nodules, carbon with extremely positive values-up to $+13.5 \%$-was derived from $\mathrm{CO}_{2}$ formed by the fermentation of organic matter or from $\mathrm{CO}_{2}$ formed by an isotopic fractionation between methane and residual carbon during degradation of limited amounts of organic carbon with incorporation of organic carbon. Regarding oxygen isotopic composition of carbonate nodules, formation water equilibrated with carbonate nodules may be enriched in ${ }^{18} \mathrm{O}$ in comparison with seawater. Carbon isotopic composition of marine organic carbon in this area is about $-21.0 \%$. Organic carbon in sediment is slightly contaminated by terrestrial material in nearshore cores. Carbon isotopic composition of organic carbon was not changed during production of methane.

\section{ACKNOWLEDGMENTS}

We wish to express our sincere thanks to Professor Nobuyuki Nakai of Nagoya University for providing the facilities for massspectrometric analysis and for constructive discussions. Thanks are extended to Professors T. L. Ku and D. S. Gorsline of the University of Southern California, to Dr. J. R. Hein of the U.S. Geological Survey, and to Professor Kazuo Taguchi of Tohoku University and Dr. Shoji Arai of Shizuoka University for their critical readings of the manuscript. We are also indebted to Professor Noriyuki Nasu of the Ocean Research Institute, University of Tokyo, for arranging the preparation of most of the thin sections of carbonate nodules. We wish to thank Associate Professor Masahiro Ito of Nagoya University for providing us with DTA data and Messrs. Takahiro Kamiya, Izumi Takemoto, and Masato Koyama of Shizuoka University for their assistance in taking the SEM micrographs.

\section{REFERENCES}

Aizenshtat, Z., Baedecker, M. J., and Kaplan, I. R., 1973. Distribution and diagenesis of organic compounds in JOIDES sediments from Gulf of Mexico and western Atlantic. Geochim. Cosmochim. Acta, 37:1881-1898.

Anderson, T. F., and Lawrence, J. R., 1976. Stable isotope investigations of sediments, basalts, and authigenic phases from Leg 35 cores. In Hollister, C. D., Craddock, C., et al., Init. Repts. DSDP, 35: Washington (U.S. Govt. Printing Office), 497-505.

Boersma, A., and Shackleton, N., 1977. Tertiary oxygen and carbon isotope stratigraphy, Site 357 (Mid-Latitude South Atlantic). In Supko, P. R., Perch-Nielsen, K., et al., Init. Repts. DSDP, 39: Washington (U.S. Govt. Printing Office), 911-924.

Cheney, E. S., and Jensen, M. L., 1965. Stable carbon isotopic composition of biogenic carbonates. Geochim. Cosmochim. Acta, 29: $1331-1346$.

Claypool, G. E., Presley, B. J., and Kaplan, I. R., 1973. Gas analyses in sediment samples from Legs 10,11, 13, 14, 15, 18, and 19. In Creager, J. S., Scholl, D. W., et al., Init. Repts. DSDP, 19: Washington (U.S. Govt. Printing Office), 879-884.

Craig, H., 1957. Isotopic standard for carbon and oxygen and correction factors for mass-spectrometric analysis for carbon dioxide. Geochim. Cosmochim. Acta, 12:133-149.

Curtis, C. D., Petrowski, C., and Oertel, G., 1972. Stable carbon isotope ratios within carbonate concretions: A clue to place and time of formation. Nature, 235:98-100.

Degens, E. T., Guillard, R. R. L., Sacket, W. M., et al., 1968. Metabolic fractionation of carbon isotopes in marine plankton-I. Temperature and respiration experiments. Deep-Sea Res., 15:1-9.

De Giovani, W. F., Salati, E., Marini, O. J., et al., 1974. Unusual isotopic composition of carbonates from the Irati Formation, Brazil. Geol. Soc. Am. Bull., 85:41-44.

Deuser, W. G., 1970. Extreme ${ }^{13} \mathrm{C} /{ }^{12} \mathrm{C}$ variations in Quaternary dolomites from the continental shelf. Earth Planet. Sci. Lett., 8:118124.

Epstein, S., and Lowenstam, H. A., 1953. Temperature-shell-growth relations of recent and interglacial Pleistocene shoal-water biota from Bermuda. J. Geol., 61:424-438.

Folk, R. L., 1962. Spectral subdivision of limestone types. In Ham, W. E. (Ed.), Classification of Carbonate Rocks: AAPG Mem. 1, pp. $62-84$.

Fritz, P., Binda, P. L., Folinsbee, F. E., et al., 1971. Isotopic composition of diagenetic siderites from Cretaceous sediments in western Canada. J. Sediment. Petrol., 41:282-288.

Galimov, E. M., Girin, Yu. P., and Vernadskiy, V. P., 1968. Variation in the isotopic composition of carbon during the formation of carbonate concretions. Geochem. Int., 5:178-182.

Goldsmith, J. R., Graf, D. L., and Heard, H. C., 1961. Lattice constants of calcium-magnesium carbonates. Am. Mineral., 46:453457.

Hahn-Weinheimer, P., Fabricius, F., Müller, J., et al., 1978. Stable isotopes of oxygen and carbon in carbonates and organic material from Pleistocene sediments at Site 374 (DSDP Leg 42A). In Hsü, K. J., Montadert, L., et al., Init. Repts. DSDP, 42, Pt. 1: Washington (U.S. Govt. Printing Office), 483-488.

Hathaway, J. C., and Degens, E. T., 1969. Methane-derived marine carbonates of Pleistocene age. Science, 165:690-692.

Hedges, J. I., and Parker, P. L., 1976. Land-derived organic matter in surface sediments from the Gulf of Mexico. Geochim. Cosmochim. Acta, 40:1019-1029.

Hein, J. R., O'Neil, J. R., and Jones, M. G., 1979. Origin of authigenic carbonates in sediment from the deep Bering Sea. Sedimentology, 29:681-705.

Hirabayashi, K., 1977. Sedimentological and geochemical study on carbonate concretions in the Joban coal-field and Oga Peninsula, Northeast Japan. Sci. Rept. Tohoku Univ. Ser. 3, 13:183-226.

Hodgson, W. A., 1966. Carbon and oxygen isotope ratios in diagenetic carbonates from marine sediments. Geochim. Cosmochim. Acta, 30:1223-1233.

Irwin, H., Curtis, C. D., and Coleman, M., 1977. Isotopic evidence for source of diagenetic carbonates formed during burial of organic-rich sediments. Nature, 269:209-213.

Kharaka, Y. K., and Berry, F. A. F., 1973. Isotopic composition of oil-field brines from Kettleman North Dome, California, and their geologic implications. Geochim. Cosmochim. Acta, 37:18991908.

Lawrence, J. R., 1973. Interstitial water studies, Leg 15-Stable oxygen and carbon isotope variation in water, carbonates and silicates from the Venezuela Basin (Site 149) and the Aves Rise (Site 148). In Heezen, B. C., MacGregor, I. D., et al., Init. Repts. DSDP, 20: Washington (U.S. Govt. Printing Office), 891-899. 
, 1974. Stable oxygen and carbon isotope variations in the pore waters, carbonates and silicates, Sites 225 and 228, Red Sea. In Whitmarsh, R. B., Weser, O. E., Ross, D. A., et al., Init. Repts. DSDP, 23: Washington (U.S. Govt. Printing Office), 939942.

Lippmann, F., 1973. Sedimentary carbonate minerals: New York (Springer-Verlag).

McCrea, J. M., 1950. The isotopic chemistry of carbonates and a paleotemperature scale. J. Chem. Phys., 18:849-857.

McKenzie, J. A., and Ricchiuto, T. E., 1978. Stable isotopic investigation of carbonate samples related to the Messinian salinity crisis from DSDP Leg 42A, Mediterranean Sea. In Hsü, K. J., Montadert, L., et al., Init. Repts. DSDP, 42, Pt. 1: Washington (U.S. Govt. Printing Office), 650-655.

Milliman, J. D., Ross, D. A., and Ku, T., 1969. Precipitation and lithification of deep-sea carbonates in the Red Sea. J. Sediment. Petrol., 39:724-736.

Mizutani, Y., and Oana, S., 1973. Separation of $\mathrm{CO}_{2}$ from $\mathrm{SO}_{2}$ with frozen $n$-pentane as a technique for the precision analysis of ${ }^{18} \mathrm{O}$ in sulfate. Mass Spectros. Tokyo, 21:255-258.

Murata, K. J., Friedman, I., and Madsen, B. M., 1969. Isotopic composition of diagenetic carbonates in marine Miocene formations of California and Oregon. Geol. Surv. Prof. Pap., 614B, B1-B24.

Nakai, N., Wada, H., Kiyosu, Y., et al., 1975. Stable isotope studies of the salt and water from Lake Vanda, Dry Valley, AntarcticaOrigin of salt and water, and the geologic history of the lake. Geochem. J., 9:7-24.

Nissenbaum, A., Presley, B. J., and Kaplan, I. R., 1972. Early diagenesis in a reducing fjord, Saanich Inlet, British Columbia-I. Chemical and isotopic changes in major components of interstitial water. Geochim. Cosmochim. Acta, 36:1007-1027.

Okada, H., 1980. Pebbles and carbonate nodules from Deep Sea Drilling Project Leg 56 cores. In Scientific Party, Init. Repts. DSDP, 56, 57, Pt. 2: Washington (U.S. Govt. Printing Office), 1089-1106.
Perry, E. A., Jr., Gieskes, J. M., and Lawrence, J. R., 1976. Mg, Ca, and $\mathrm{O}^{18} / \mathrm{O}^{16}$ exchange in the sediment-pore water system, Hole 149, DSDP. Geochim. Cosmechim. Acta, 40:413-423.

Roberts, H. H., and Whelan, T., III, 1975. Methane-derived carbonate cements in barrier and beach sands of a subtropical delta complex. Geochim. Cosmochim. Acta, 39:1085-1089.

Rosenfeld, W. D., and Silverman, S. R., 1959. Carbon isotope fractionation in bacterial production of methane. Science, 130:16581659.

Sackett, W. M., 1964. The depositional history and isotopic carbon composition of marine sediments. Mar. Geol., 2:173-185.

Sackett, W. M., and Thompson, R. R., 1963. Isotopic organic carbon composition of recent continental derived clastic sediments of the eastern Gulf Coast, Gulf of Mexico. Am. Assoc. Pet. Geol., 47: 525-531.

Schidlowski, M., Eichmann, R., and Junge, C. E., 1976. Carbon isotope geochemistry of the Precambrian Lomagundi carbonate province, Rhodesia. Geochim. Cosmochim. Acta, 40:449-455.

Sharma, T., and Clayton, R. N., 1965. Measurement of $\mathrm{O}^{18} / \mathrm{O}^{16}$ ratios of total oxygen from carbonates. Geochim. Cosmochim. Acta, 29:1347-1354.

Smith, B. N., and Epstein, S., 1971. Two categories of ${ }^{13} \mathrm{C} /{ }^{12} \mathrm{C}$ ratios for higher plant. Plant Physiol., 47:380-384.

Suss, E., and Kolodny, Y., 1972. Stable isotopes, chemistry and petrology of carbonate concretions (Mishash Formation, Israel). Chem. Geol., 10:261-286.

Tarutani, T., Clayton, R. N., and Mayeda, T. K., 1969. The effect of polymorphism and magnesium substitution on oxygen isotope fractionation between calcium carbonates and water. Geochim. Cosmochim. Acta, 33:987-996.

Weber, J. N., Williams, E. G., and Keith, M. L., 1964. Paleoenvironmental significance of carbon isotopic composition of siderite nodules in some shales of Pennsylvanian age. J. Sediment. Petrol., 34:814-818. 

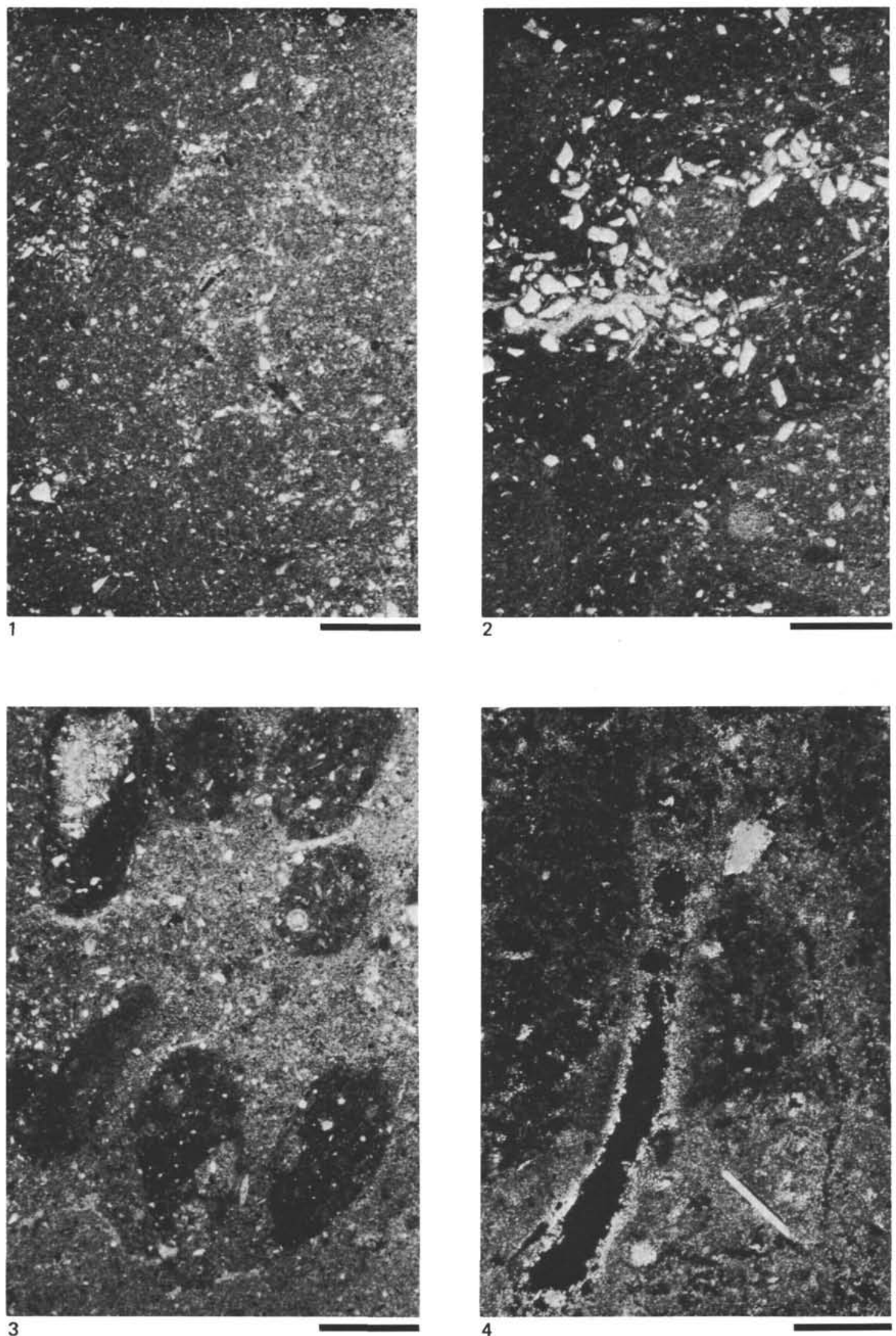

Plate 1. (Scale bar $=0.5 \mathrm{~mm})$. 1. Pelmicrite showing pellets paved with silt grains along the margin of pellets (Sample 490-1-4, 82-84 $\mathrm{cm}$ ). Plane polarized light. 2. Pelmicrite showing concentration of silt grains between pellets (Sample 490-29-4, 128-132 cm). Plane polarized light. 3. Pelmicrite (Sample 491-6-1, 20-22 cm). Plane polarized light. 4. Pelmicrite showing original cavities between pellets (cavity in black) (Sample 491-6-1, 4-6 cm). Crossed nicols. 

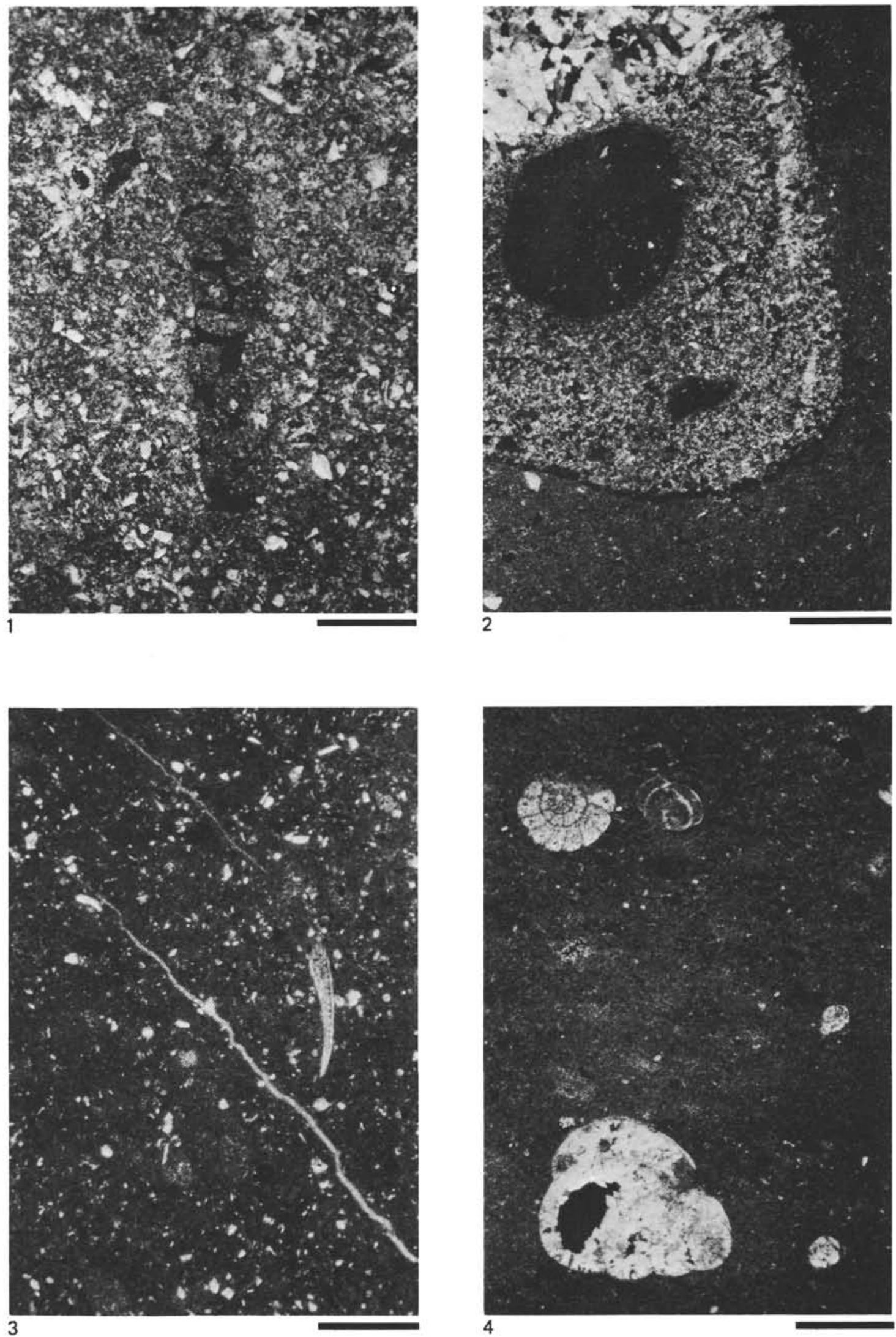

Plate 2. (Scale bar $=0.5 \mathrm{~mm}$ ). 1. Pelmicrite with a burrow full of small pellets (Sample 490-37-3, 0-5 cm). Plane polarized light. 2. Pelmicrite showing a burrow filled with lime muds and secondary calcite spars, containing pellets (Sample 491-6-1, 20-22 cm). Plane polarized light. 3. Calcite veinlets in micrite (Sample 491-4-1,16-18 cm). Plane polarized light. 4. Micrite showing chambers of foraminifers partially filled with calcite spars (pore in black) (Sample 493-8-2, 49-51 cm). Crossed nicols. 

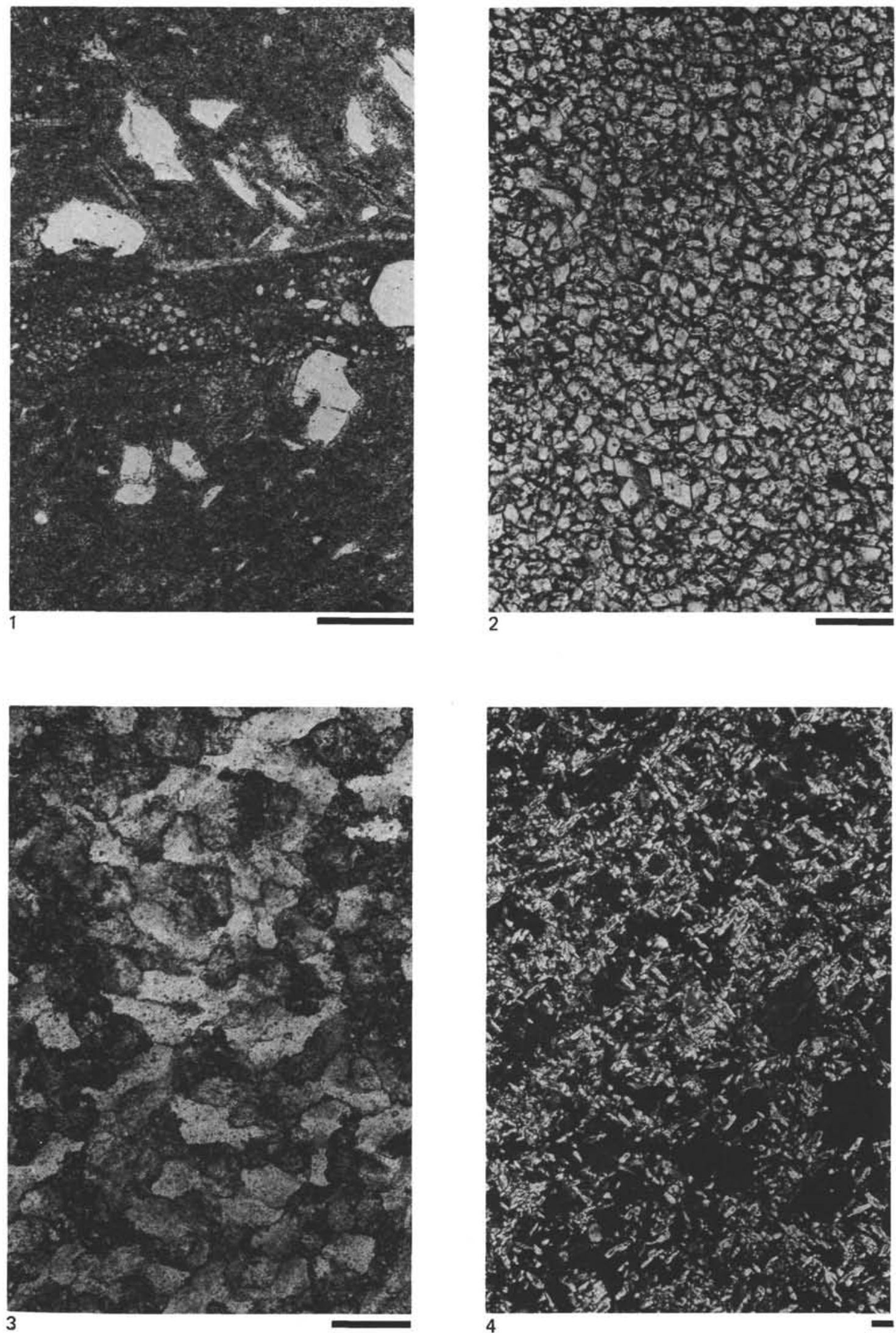

Plate 3. 1. Micrite with dolomite layer at the middle of the photo (Sample $490-29-4,128-132 \mathrm{~cm}$ ). Scale bar $=0.5 \mathrm{~mm}$. Plane polarized light. 2. Dolomite (Sample 493B-10-1,20-22 cm). Scale bar $=0.1 \mathrm{~mm}$. Plane polarized light. 3. Recrystallized limestone composed wholly of rhodochrosite (Sample 487-16-1, 13-16 cm). Scale bar = 0.1 mm. Plane polarized light. 4. Blade-shaped calcite crystals (Sample 490-2-1, 10-12 $\mathrm{cm})$. Scale bar $=0.01 \mathrm{~mm}$. Crossed nicols. 

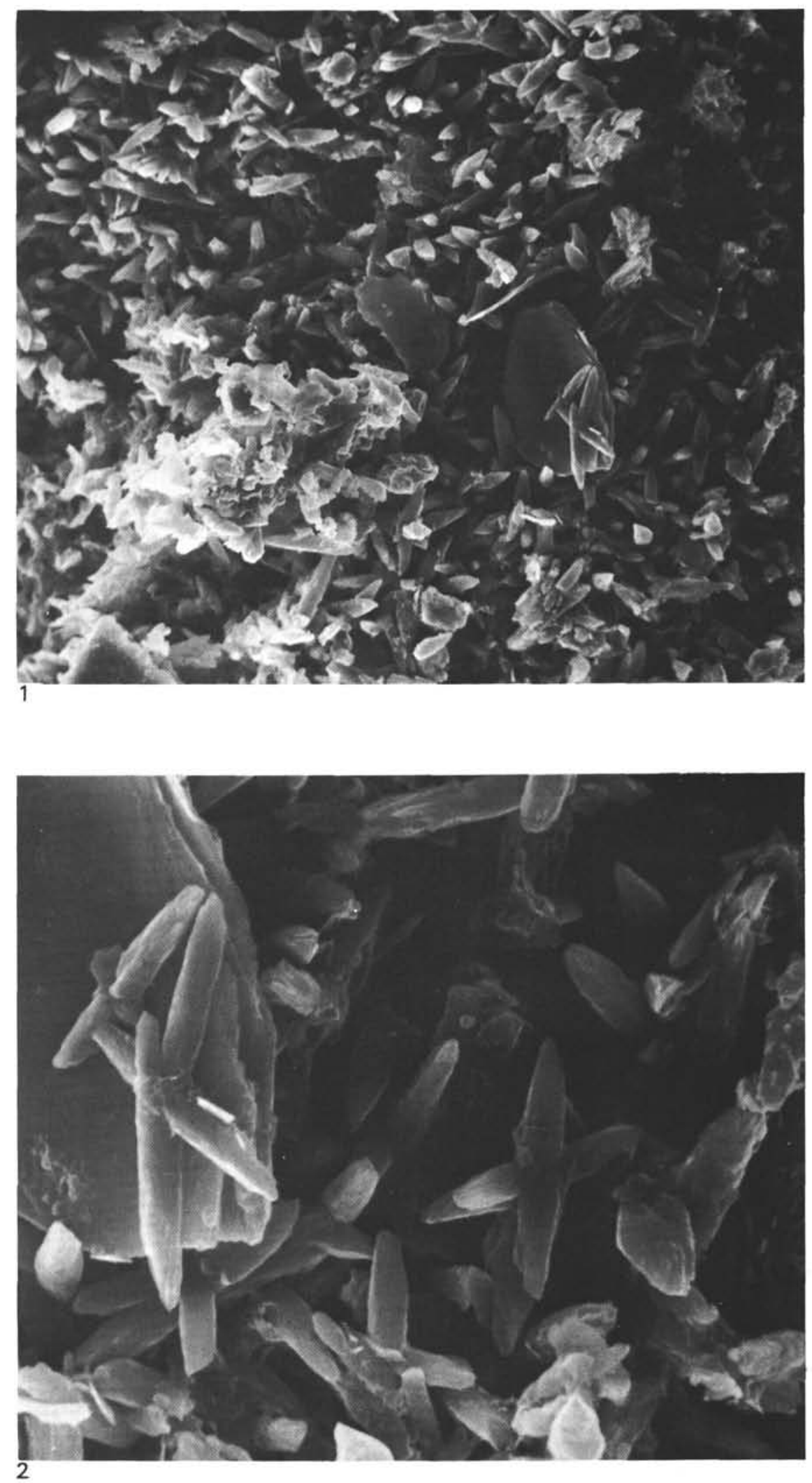

Plate 4. (Sample 490-2-1, 10-12 cm). 1. Fracture surface showing blade-shaped calcite crystals $\left(\delta^{13} \mathrm{C}=6.2 \%, \delta^{18} \mathrm{O}=+6.2 \%\right.$ ). $\times 660.2 . \quad$ Magnified blade-shaped calcite crystals. $\times 2000$. 

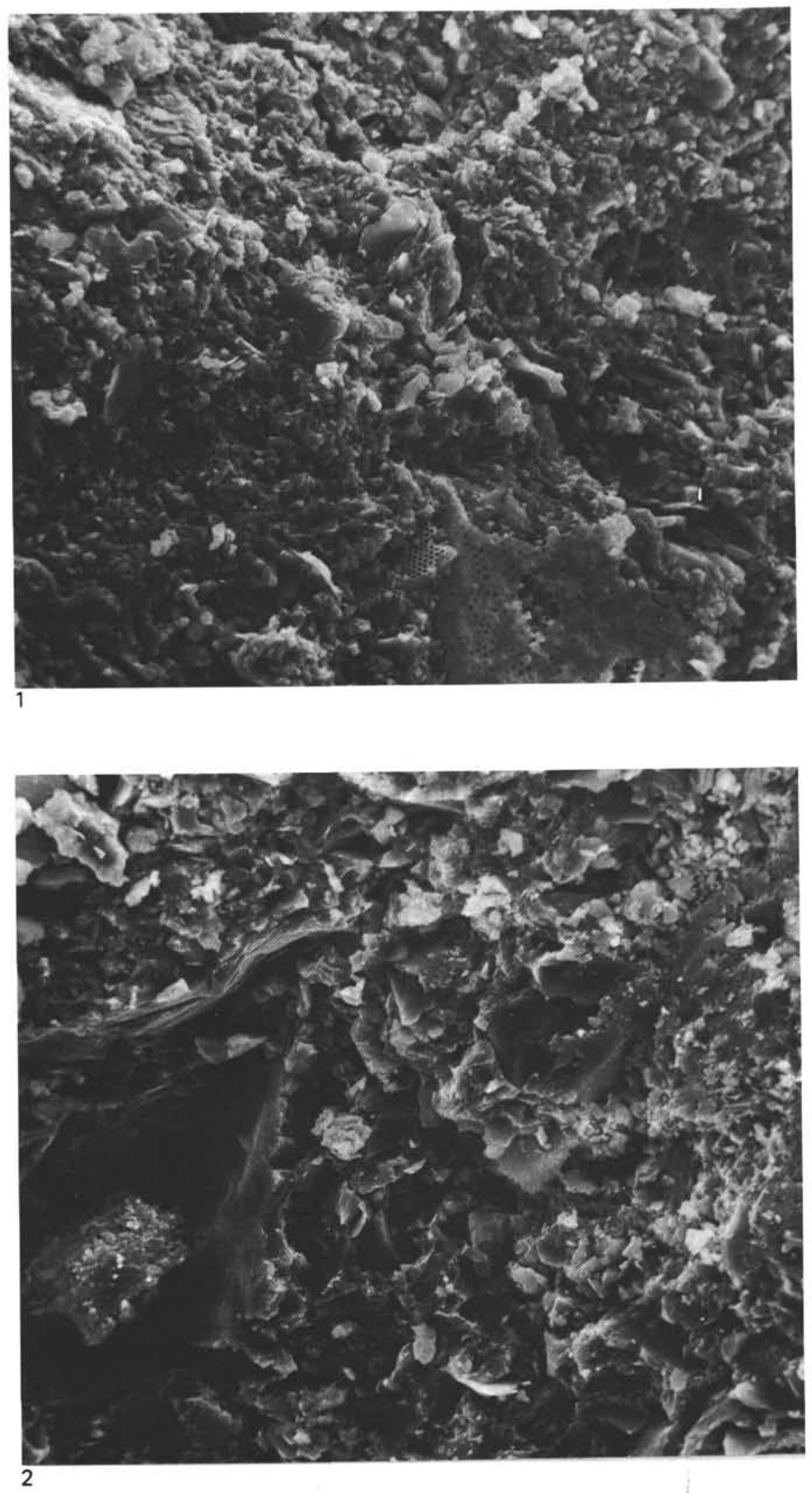

Plate 5. (Magnification $\times 660)$. 1. Fracture surface of Sample $490-1-4,82-84 \mathrm{~cm}$. Calcite $\left(\delta^{13} \mathrm{C}=-10.1 \%, \delta^{18} \mathrm{O}=+5.3 \%\right.$ ). 2 . Fracture surface of Sample 491-6-1, 20-22 cm. Calcite $\left(\delta^{13} \mathrm{C}=-37.5 \%, \delta^{18} \mathrm{O}=+4.0 \%\right)$. 

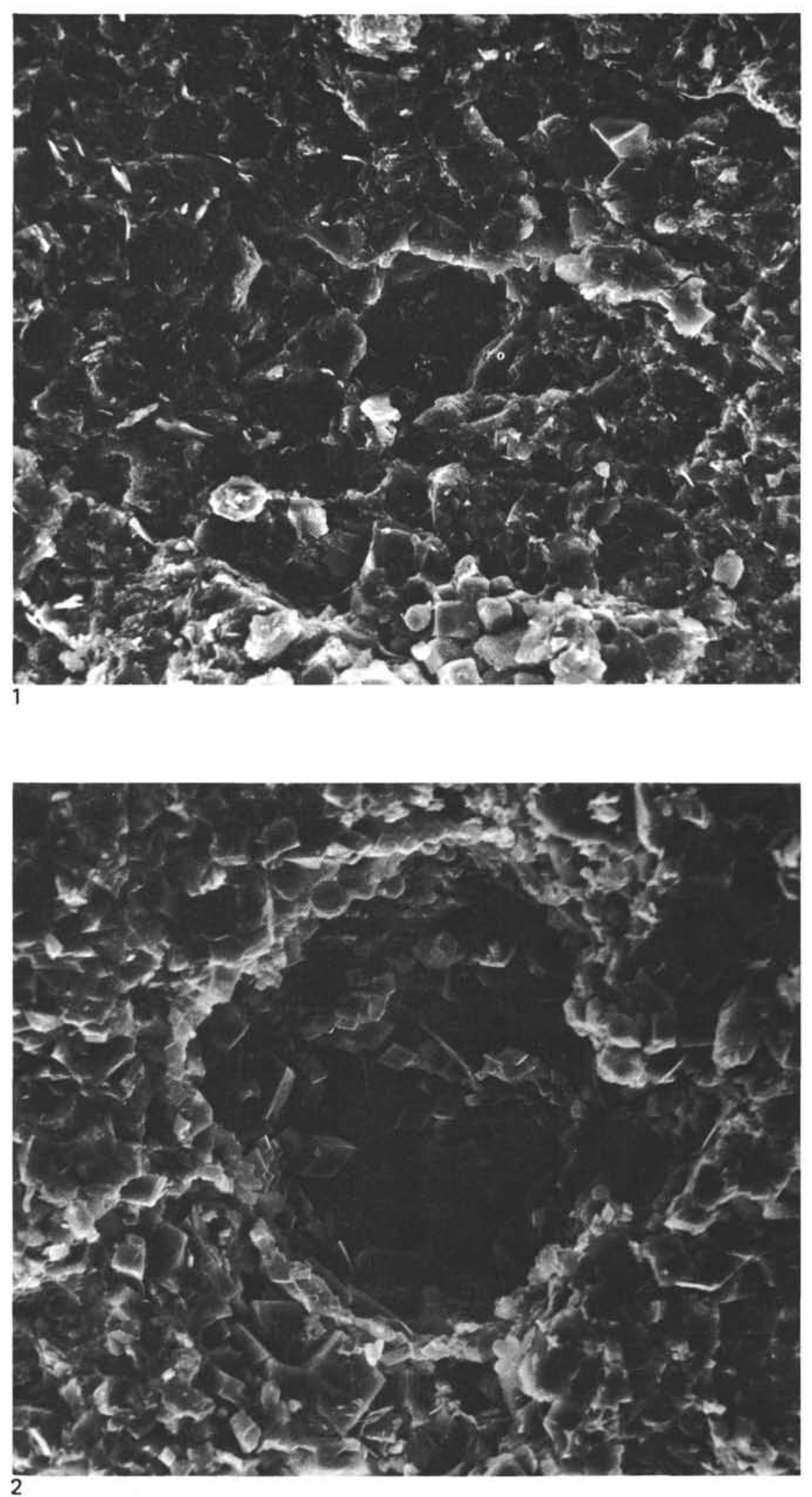

Plate 6. (Magnification $\times 660$ ). 1. Fracture surface of Sample $493-11-3,54-56 \mathrm{~cm}$. Dolomite $\left(\delta^{13} \mathrm{C}=+13.5 \%\right.$, $\delta^{18} \mathrm{O}=+4.3 \%$ ). 2 . Fracture surface of Sample 493B-10-1, 51-53 cm. Dolomite $\left(\delta^{13} \mathrm{C}=-14.6 \%, \delta^{18} \mathrm{O}=+5.5 \%\right.$ ). 

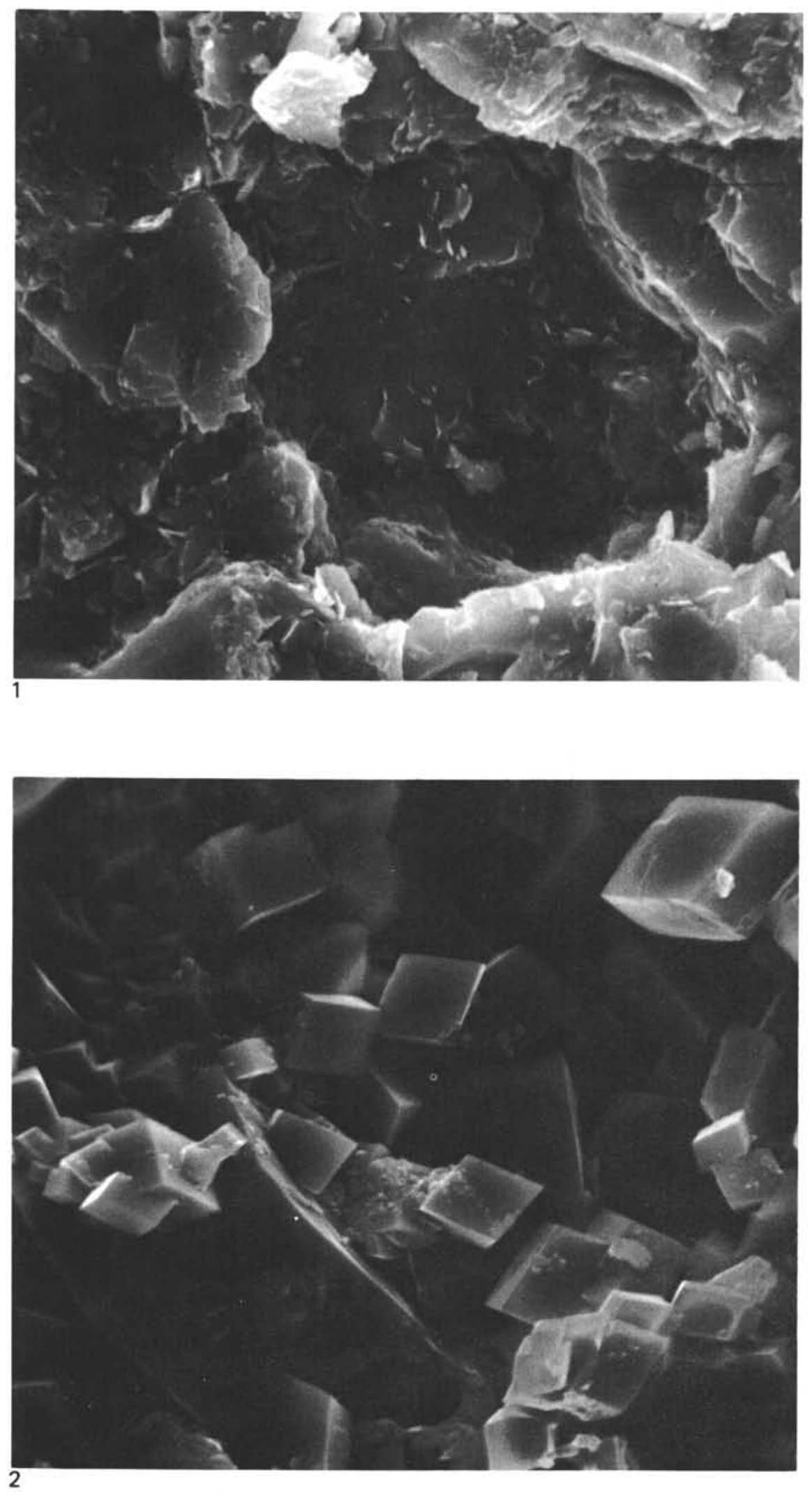

Plate 7. (Magnification $\times 2000$ ). 1. Magnified fracture surface of Sample 493-11-3, 54-56 cm. 2. Magnified fracture surface of Sample 493B-10-1, 51-53 cm. 

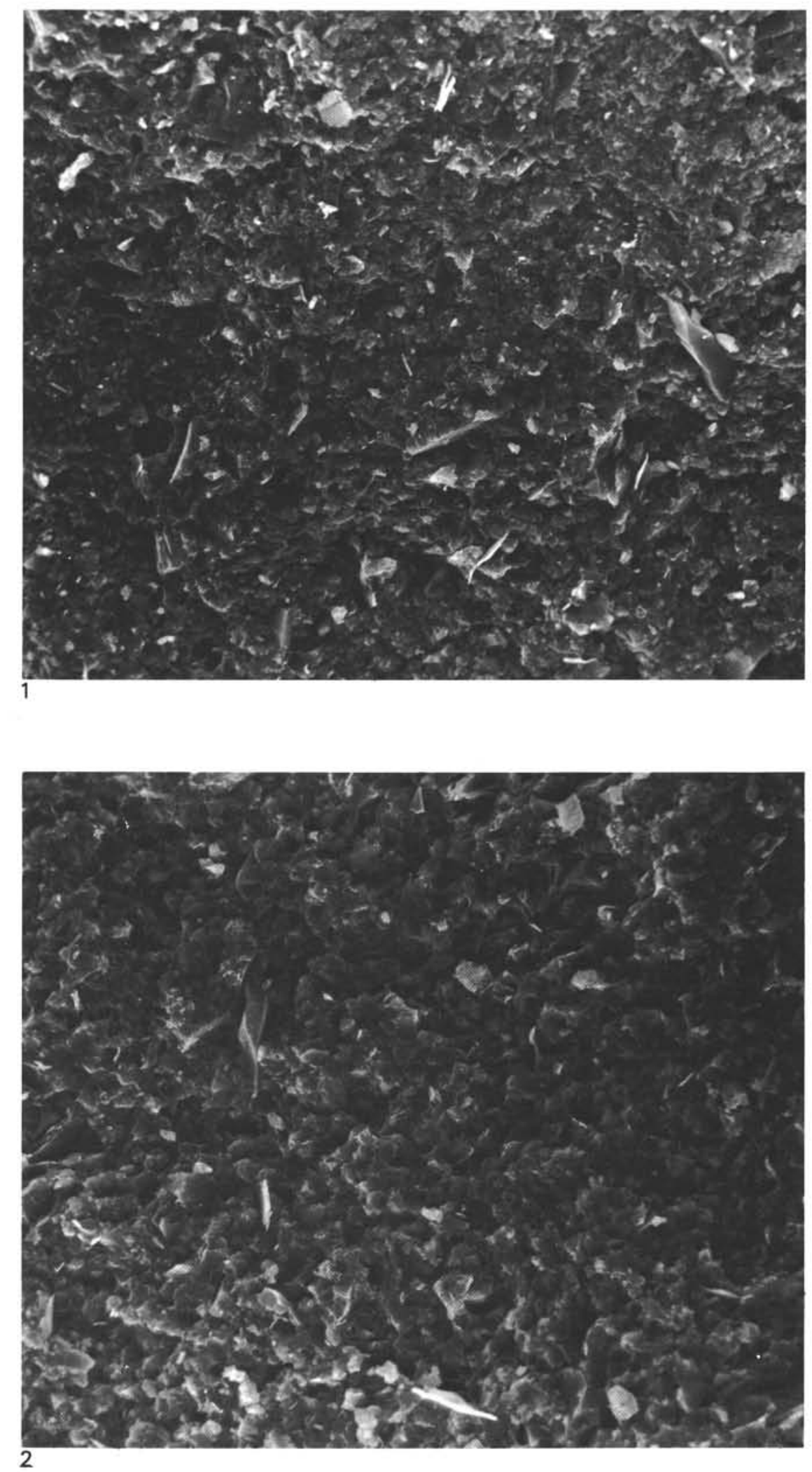

Plate 8. (Magnification $\times 660$ ). 1. Fracture surface of Sample $490-29-4,128-132 \mathrm{~cm}$. Dolomite $\left(\delta^{13} \mathrm{C}=-14 \cdot 0 \%, \delta^{18} \mathrm{O}=+5.9 \%\right)$. 2. Fracture surface of Sample 493-8-2, $49-51 \mathrm{~cm}$. Dolomite $\left(\delta^{13} \mathrm{C}=+5.4 \%_{0}, \delta^{18} \mathrm{O}=+4.3 \%_{0}\right)$. 

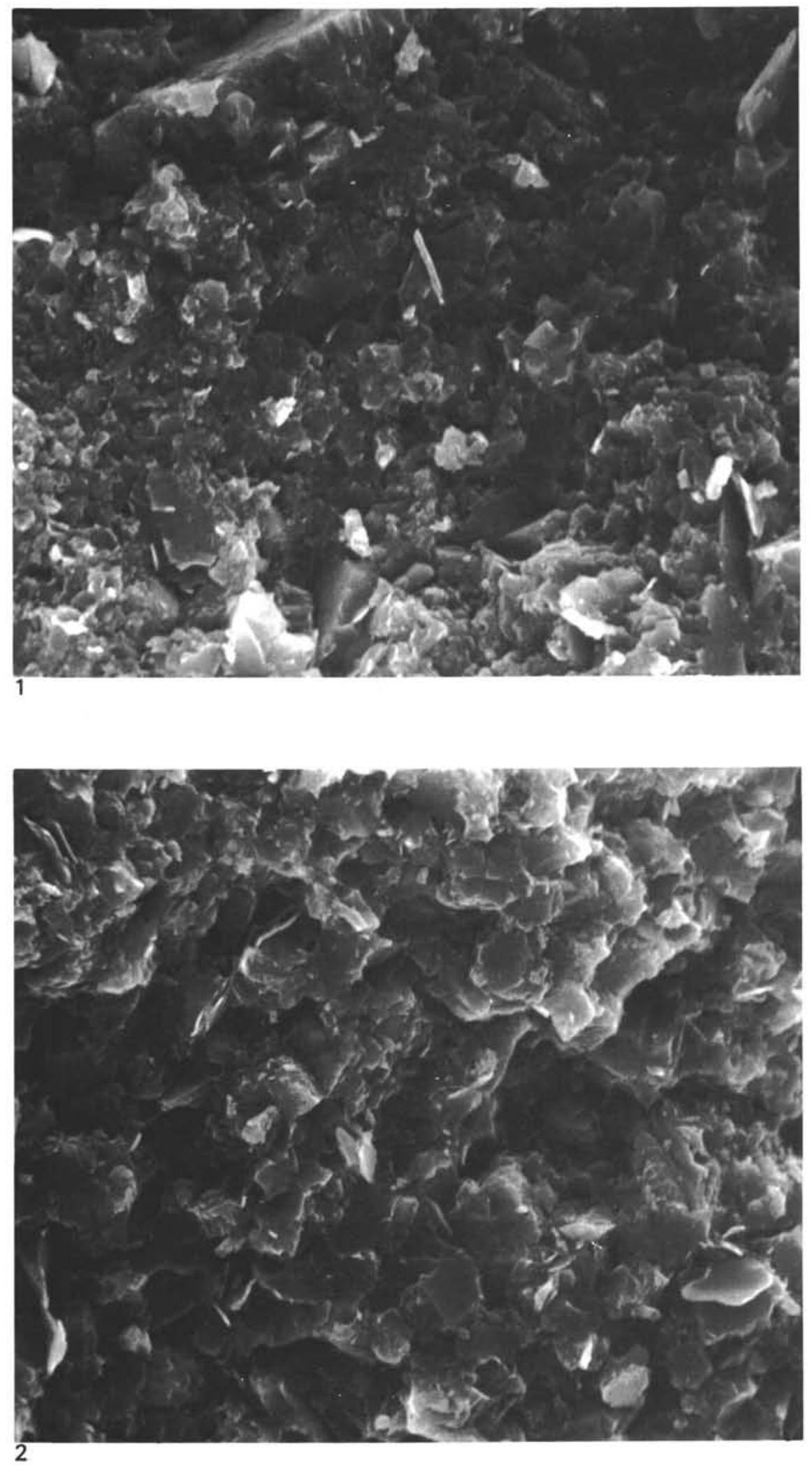

Plate 9. (Magnification $\times 2000$ ). 1. Magnified fracture surface of Sample 490-29-4, 128-132 cm. 2. Magnified fracture surface of Sample 483-8-2, 49-51 cm. 
H. WADA, N. NIITSUMA, K. NAGASAWA, H. OKADA

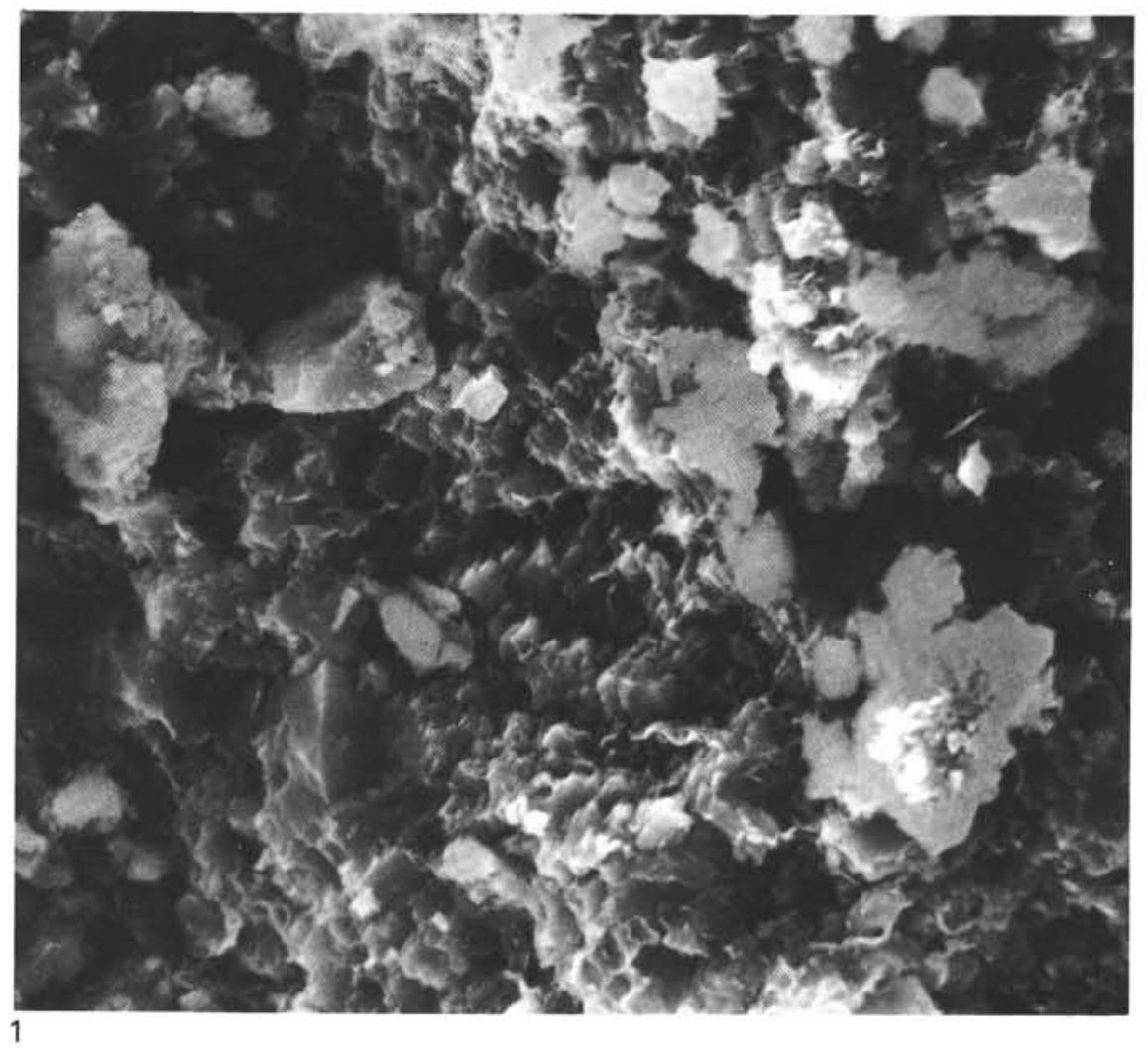

Plate 10. Fracture surface of Sample $487-16-1,10-12 \mathrm{~cm}$. Rhodochrosite $\left(\delta^{13} \mathrm{C}=-2.9 \%, \delta^{18} \mathrm{O}=+7.6 \%\right.$. $\times 2000$. 